\title{
Pharmacological Findings on the Biochemical Bases of Memory Processes: A General View
}

\author{
Iván Izquierdo, Martín Cammarota, Jorge H. Medina and Lia R.M. Bevilaqua \\ Centro de Memoria, Departamento de Bioquímica, Instituto de Ciencias Básicas da Saúde, \\ Universidade Federal do Rio Grande do Sul, Ramiro Barcelos 2600-anexo (90035-003) \\ Porto Alegre, RS, Brasil
}

\section{SUMMARY}

We have advanced considerably in the past 2 to 3 years in understanding the molecular mechanisms of consolidation, retrieval, and extinction of memories, particularly of fear memory. This advance was mainly due to pharmacological studies in many laboratories using localized brain injections of molecularly specific substances. One area in which significant advances have been made is in understanding that many different brain structures are involved in different memories, and that often several brain regions are involved in processing the same memory. These regions can cooperate or compete with each other, depending on circumstances that are beginning to be identified quite clearly. Another aspect in which major advances were made was retrieval and post-retrieval events, especially extinction, pointing to new therapeutic approaches to fearmotivated mental disorders.

\section{KEYWORDS}

memory mechanisms, memory retrieval, memory consolidation, memory extinction

Reprint requests to: I. Izquierdo Inst. de Pesquisas Biomedicas, Hospital Sao Lucas PUCRS Av Ipiranga, 6690 - 20. andar (90610-000) Porto Alegre, RS; e-mail: izquier@terra.com.br;

Study supported by CNPQ, Brasil

\section{INTRODUCTION}

Most of what we know about the biochemistry of memory processes has come from pharmacological experiments. We recently published several extensive reviews on this subject in relation to memory consolidation (Izquierdo \& McGaugh, 2000; McGaugh \& Izquierdo, 2000), the dichotomy between short- and long-term memory (Izquierdo et al., 1999; Izquierdo et al., 2002), retrieval (Barros et al., 2003), and extinction (Vianna et al., 2003).

In addition, several other recent and excellent accounts of special aspects of these subjects have emerged: the role of glutamate receptors in memory processes (Castellano et al., 2001; Riedel et al., 2003), the molecular pharmacology of extinction (Myers \& Davis, 2002), molecular models of human cognition deficits involving alterations of phosphorylation of the transcription factor CAMPresponse element binding protein (CREB) (Weeber \& Sweatt, 2002), or disruptions of calcium/calmodulin-dependent protein kinase (PK) II activity (Weeber et al., 2003), the role of the amygdala in consolidation (McIntyre et al., 2003) and extinction (Davis et al., 2003) and others. A recent book edited by Riedel and Platt (2003) contains chapters reviewing most aspects mentioned above and others in detail.

Here we review papers published between mid-2001 and October 2003 on pharmacological findings that shed light on the biochemistry of consolidation, retrieval, and extinction that are 
therefore generally not covered by the articles mentioned above. Topics that are being currently studied in this laboratory, but for which the results are still a long way from becoming definitive, will not be reviewed. These areas include the role of the cellular prion protein (Martins e $t$ al., 2002; Coitinho et al., 2002; Martins et al., 2003) and the role of brain ectonucleotidases in memory processes (Pereira et al., 2002). The two subjects may be interrelated (Pereira et al., 2001).

\section{MEMORY MECHANISMS: A GENERAL VIEW}

Pharmacological experiments, often corroborated by studies using genetic manipulation, have established the major molecular mechanisms of memory consolidation and certain mechanisms involved in retrieval and extinction. The most useful studies have usually been carried out using small and slow stereotaxic infusions of drugs into restricted brain areas. The infused material reaches not more than $1 \mathrm{~mm}^{3}$ of brain tissue and diffuses away from the infusion site with a time constant of 30 min or less (Martin, 1991; Ardenghi et al., 1997; Barros et al., 2000, 2001). Larger or faster infusions yield data that are difficult to interpret and will not be commented upon here. In certain instances, systemic administration produced relevant findings, however, depending on the drug chosen.

Most studies have been carried out on the hippocampus, the brain structure most involved in memory processing and/or the main structure responsible for the consolidation, retrieval, and extinction of many tasks in animals and humans (Eichenbaum et al., 1996; Bunsey, 1996; Izquierdo \& Medina, 1997; Izquierdo \& McGaugh, 2000; Izquierdo et al., 2002; Barros et al., 2003; Sacchetti et al., 1999). Several studies, however, have addressed other brain structures thought to be responsible for the consolidation of certain types of fear memory, such as the amygdala (Miserendino et al., 1990; Bevilaqua et al., 1997; Myers
\& Davis, 2002), various regions of the cortex (Ardenghi et al., 1997) and, as will be seen below, the nucleus accumbens (Sargolini et al., 2003) and the striatum (Prado-Alcalá et al., 2003). Brioni (1993) was perhaps the first to state formally that consolidation is not the result of the operation of any single brain structure but of many structures that are linked to one another and with the hippocampus, as borne out by many experiments (Ardenghi et al., 1997; Izquierdo et al., 1997; Izquierdo \& Medina, 1997; Sacchetti et al., 1999; Izquierdo \& McGaugh, 2000; Bonini et al., 2003; Rosatto et al., 2003). The days in which the hippocampus was attributed a role only in spatial tasks (Morris et al., 1986) or contextual learning (Hirsh, 1974) are gone; hundreds of papers on brain lesions, functional inactivation, drug effects in animals, and functional magnetic resonance in humans attest to the generality of the role of the hippocampus and its connections in many forms of memory (see Eichenbaum et al., 1996; Izquierdo \& Medina, 1997; McGaugh \& Izquierdo, 2000).

In the CA1 region of the rat hippocampus, consolidation processes involve initially the activation of glutamate N-methyl-D-aspartate (NMDA; Morris et al., 1986; Izquierdo et al., 1992), alpha-amino-3-hydroxy-5-methylisoxazole4-propionic acid (AMPA; Jerusalinsky et al., 1992, 1992) and metabotropic receptors (m-GluRs; Bianchin et al., 1996), enhanced by the influence of presynaptic $\gamma$-PKC on the vesicle-mobilizing substrate GAP-43 (Colley \& Routtenberg, 1993; Cammarota et al., 1997; Routtenberg, 2000; Paratcha et al., 2000) and by nitric oxide (NO), carbon monoxide (C), and the platelet-activating factor released from the postsynaptic terminal (Izquierdo et al., 1995; Medina \& Izquierdo, 1995) with the intervention of PKG; Bernabeu et al., 1996). At this early stage, the main brake on memory formation is the widespread net of $\mathrm{GABA}_{\mathrm{A}}$ receptors acting simultaneously in CA1, amygdala, medial septum, cortex, and other parts of the brain (Izquierdo et al., 1992; Brioni, 1993). 
Right after training, post-synaptic $\beta$-PKC activity (Paratcha et al., 2000; Routtenberg, 2000), PKA (Bernabeu et al., 1997) and calcium/calmodulindependent PK II (CaMKII) activity is enhanced; the latter phosphorylates the GluR1 subunit of the AMPA receptor (Cammarota et al., 1998). In rat hippocampus, high levels of AMPA binding follow single aversive training experiences (Cammarota et al., 1996). Protein kinase A, PKC, and CaMKII phosphorylate several substrates. Inhibitors of these enzymes given immediately post-training into the CAl region of the hippocampus cancel memory consolidation (Izquierdo \& Medina, 1997). Gene expression and protein synthesis at that time are crucial for long-term, but not for short-term memory formation (Igaz et al., 2002).

In the first hour after training, PKA, PKC, and CaMKII enzyme activity declines and consolidation becomes gradually less sensitive to inhibitors. At that time, however, hippocampal PKA is essential for maintaining short-term memory alive for the next 3 to $5 \mathrm{~h}$ (Vianna et al., 2000). At 2 to $3 \mathrm{~h}$ after training, the activity of PKA increases again in CAl and this-together with a parallel activation of mitogen-activated kinase (MAPK) pathways-is essential for longterm memory to become established. This activity depends on the previous activation of NMDA receptors in CA1 by training (Cammarota et al., 2000) and, in the case of PKA, on the preceding immediate post-training PKA peak mentioned above (Vianna et al., 2000).

The late wave of PKA and extra-cellular signalregulated kinase (ERK) activity in CA1 coincides with an an increased phosphorylation of the transcription factor CREB and with a second wave of sensitivity to inhibitors of gene expression and protein synthesis given into CAl (Igaz et al., 2002). Early studies on RNA and protein content measured at different times after behavioral training have signaled the existence of this double wave of metabolic activity in the hippocampus as necessary for long-term memory formation
(Matthies, 1989). At this stage, memory is sensitive to the facilitator role of dopamine D1 and $\beta$-noradrenergic and the deleterious influence of serotonin (5HT-1A) receptors in CA1 and elsewhere on memory consolidation, which extends up to $6 \mathrm{~h}$ post-training (Ardenghi et al., 1997).

The hippocampus is known to be essential for retrieval (Squire et al., 1992; Eldridge et al., 2000; Corcoran \& Maren, 2001). Other brain structures, however, are also involved. Recent studies in rats show that retrieval of one-trial inhibitory avoidance requires intact AMPA receptors in CA1, entorhinal cortex, parietal cortex, and amygdala; intact NMDA receptors in the anterior cingulate cortex; and intact glutamate mGluRs in CA1 and in the entorhinal, parietal, and anterior cingulate cortex, but not in the amygdala. In addition, retrieval requires normal PKA and ERK activity (Barros et al., 2000) in all these brain structures.

The biochemical requirements of extinction have been examined for a variety of conditionedfear tasks in recent years, and the findings are summarized in Myers and Davis (2002), Bahar et al. (2003) and Vianna et al., (2003). Pharmacological studies have shown that gene expression, protein synthesis, and PKA mitogen-activated protein kinase (MAPK)/ERK activity in the hippocampus and basolateral amygdala are necessary for the generation of extinction, beginning at the first nonreinforced retention test. Variations with the task and the involvement of other structures in parallel to and/or instead of the hippocampus and amygdala are discussed by Vianna et al., (2003). One structure is the insular cortex in the case of conditioned taste aversion (Berman \& Dudai, 2001).

\section{GLUTAMATE RECEPTORS AND RELATED MECHANISMS}

The effect on learned behavior of NMDA receptors blockade induced by 2-amino-5-phosphonopentanoic acid (AP5) or its analogs in 
restricted brain areas is conventionally taken as an indication that such areas are crucially involved in the early stages of memory consolidation (Morris et al., 1986; Izquierdo et al., 1992). Recently, the blockade of NMDA receptors in the prelimbic cortex was found to induce amnesia for odorreward associative learning (Tronel \& Sara, 2003); When infused into the dorsal striatum, AP5 interferes with memory consolidation of spatial learning (De Leonibus et al., 2003); AP5 introduced into the telencephalon of the goldfish Carassius auratus blocks avoidance memory (Xu et al., 2003), intra-hippocampal AP5 blocks the learning of paired-associates (Day et al., 2003), and intra-accumbens infusion of AP5 or the AMPA receptor antagonist, DNQX, blocks memory of an object-recognition task in mice (Sargolini et al., 2003). In CA3, NMDA receptors have been recently reported to be critical for onetrial learning (Nakazawa et al., 2003). So, new tasks, various brain structures, and one extra species have been added to the bibliography on the role of NMDA receptors in memory consolidation. In addition, the retrograde amnesia induced by AP5 for one-trial avoidance was shown to have a different time course during the onset of its effect, depending on the brain structure into which it is infused: CA1, basolateral amygdala, and entorhinal, posterior parietal, or anterior cingulate cortex (Rosatto et al., 2003). Thus, it seems that the NMDA-receptor-mediated role of each region in consolidation starts at a different time. Clearly, everyday it becomes more evident that different tasks involve different brain areas, that these are engaged at different times, and that no learning type depends exclusively on any one given brain area. One curious result in this connection is the finding that AP5 given into the insular cortex at doses that block conditioned taste aversion do not prevent the animals from learning how to attenuate neophobia; in contrast, scopolamine does prevent such learning (Gutiérrez et al. 2003). In habituation to a novel environment, a nonassociative learning that, to an extent, involves the attenuation of neophobia, AP5 given into the hippocampus instead of into the cortex has a clear inhibitory effect (Vianna et al., 2000).

Extinction is a form of learning in which animals previously trained to associate a cue (conditioned stimulus, CS) with a reinforcement (unconditioned stimulus, US) are required to associate the cue with the lack of reinforcement; i.e., to change the previous CS-US association into a CS-no US association (Myers \& Davis, 2002; Vianna et al., 2003a, 2003b). The consolidation of extinction requires the transfer from a NMDAindependent to a NMDA-dependent memory (Santini et al., 2001). The requirement of NMDA receptors for the extinction of aversive tasks at the time of the first extinction trial has been shown by the use of AP5 in both the amygdala for conditioned startle (Falls et al., 1992) and the hippocampus for one-trial avoidance (Szapiro et al., 2003).

The precise synapses at which NMDA receptors participate in consolidation in the hippocampus or elsewhere are generally not known and are vaguely hinted at. For example, the Schaeffer collateral synapses with CA1 (Izquierdo et al., 1992) and the synapses between the mossy fibers and CA3 (Nakazawa et al., 2003) are highly suspect of being involved. In the amygdala, microdialysis techniques have shown that the visceral input mediating taste-memory formation is glutamatergic (Miranda et al., 2002). So far, morphologic changes in synapses (i.e., Geinisman et al., 2001) furnish better information about which synapses might be involved in each learning task than do pharmacologic or genetic findings.

The precise aspects of memory consolidation that are blocked by NMDA receptor inhibitors are also not known. A very elegant study using intrahippocampal and intra-amygdala infusions of AP5 suggested that different aspects of one-trial avoidance are regulated by NMDA receptors in each structure. Pre-exposure attenuated the 
amnesic effect of intra-hippocampal but not intraamygdala AP5, indicating that the hippocampus is in charge of the contextual/spatial aspects of memory for this task, whereas NMDA receptors in the amygdala would be in charge of its aversive aspects (Roesler et al., 2003; see also Sanders \& Fanselow, 2003).

Ebselen, an agent with oxidant activity at NMDA receptors, hinders memory formation (Porciuncula et al., 2002). When infused into the amygdala or given systemically, D-cycloserine, a blocker of the inhibitory glycine site at NMDA receptors, facilitates NMDA-mediated extinction of conditioned fear (Walker et al., 2002; Myers \& Davis, 2002).

Which subunits of the NMDA receptor are important for the role of this receptor in memory formation? AP5 blocks the function of the entire NMDA receptor complex. The results of transgenic mouse studies point to the NR1 subunit in the hippocampus as being critical for place perception and spatial learning (Wilson \& Tonegawa, 1997). Cammarota et al. (2000) reported a transient increase of the NR1 subunit in rat hippocampus after inhibitory avoidance training. Selective blockade of NR2B-subunit-containing NMDA receptors with ifenprodil given in the lateral nucleus of the amygdala disrupts the acquisition but not the expression of fear conditioning (Rodrigues et al., 2002). Possibly NMDA receptors composed of different subunits are involved in different tasks in different areas of the brain. Data from genetic and pharmacologic approaches can als o show discrepancies (Day \& Morris, 2001). When this occurs, trusting the pharmacologic approach is usually wise because, unlike the genetic approach, the pharmacologic approach is (a) reversible; (b) can be timed with a degree of precision; (c) does not allow for developmental corrections of the change induced; and (d) does not affect the genetic pool of the animal under observation (Routtenberg, 1995).

As shown years ago, both AMPA/kainate receptors (Jerusalinsky et al., 1992) and mGluRs (Bianchin et al., 1994; Riedel, 1996) are necessary for memory consolidation. This is true both in the hippocampus for aversive tasks and in the dorsal striatum for water-maze learning (Packard et al., 2001). The need for AMPA and mGluRs in consolidation extends much longer than that of NMDA receptors, as shown by the infusion of the AMPA receptor antagonist CNQX, the a nonNMDA receptor antagonist DNQX, MCPG ( $\alpha$-methyl-4-carboxy-phenylglycine) or the mGlu receptor antagonist dl-amino-3-phosphonopropionic acid (AP3), respectively, into CA1, basolateral amygdala, and entorhinal, parietal or cingulate cortex after one-trial avoidance learning (Bonini et al., 2003). AMPA receptors containing the GluR2 subunit are critical for stimulus-reward learning in mice (Mead \& Stephens, 2003). In the nematode, Caenorhabditis elegans GLR-1, a homolog of mammalian non-NMDA receptors appears to be critical for long-term memory formation as well (Rose et al., 2003). Experiments using DNQX and MCPG have shown that both receptor types are crucially involved in the retrieval of inhibitory avoidance in CA1, entorhinal, parietal, and anterior cingulate cortex (Barros et al., 2000). In addition, hippocampal AMPA receptors are also crucial for the recall of paired associates (Day et al., 2003).

Discrepant results concerning the relative importance of different mGluR subtypes in consolidation and retrieval have been reported. Rodrigues et al. (2002) found that $\mathrm{mGluR}_{5}$ in the lateral amygdala is necessary for fear memory formation and for long-term potentiation (LTP). Szapiro et al. (2001), using antagonists that are specific to different receptor isoforms concluded that $\mathrm{mGluR}_{2,3,4,6}$ are necessary for retrieval, and that mGluR $_{1}$ normally plays an inhibitory role. LAP4, an agonist at mGluR $_{4,6}$, decreases the central action of angiotensin II, although it has no effect of its own on acquisition, consolidation, and retrieval of one-trial avoidance (Fedosiewicz- 
Wasiluk et al., 2002). There is no question as to the involvement of mGluRs in memory formation and retrieval; but doubt remains about whether different mGluR subtypes are needed for different tasks and/or for different interactions with other systems involved in learning processes.

In the mid-nineties much interest was shown in the auto-regulation of glutamatergic synapses by the stimulation-induced release of putative retrograde messengers, the best studied of which was NO. The role of hippocampal NO and other 'retrograde messengers' in consolidation was first described almost a decade ago (see review by Medina \& Izquierdo, 1995). The topic was restudied recently in an object-recognition task (Pitsikas et al., 2002) using the systemic administration of an NO donor, molsidomine. Not surprisingly, molsidomine enhanced acquisition, storage, and retrieval. Morphine and other opiates (Izquierdo, 1991) impair memory when given posttraining and, in addition, induce state dependency of aversive tasks. Interestingly, Khavandgar et al., (2003) found that the NO synthase substrate, L-arginine, reverses the retrograde amnesia induced by morphine, whereas the NO-synthase blocker, L-nitroarginine, restores the retrograde amnesia induced by morphine in an inhibitory avoidance task.

\section{NEUROTROPHIC FACTORS}

The results of recent studies have indicated that neurotrophic factors are important for memory consolidation and recall. One study (Walz et al., 2000) showed a marked enhancement of consolidation of one-trial avoidance by the intra-hippocampal infusion of nerve growth factor (NGF); the effect correlated with increased ERK activity near the site of infusion. Two studies (Alonso et al., 2002a,b) have shown that brain-derived neurotrophic factor (BDNF) is critically involved in both the formation of short-term and the long-term memory of one-trial avoidance in the rat, also via the activation of the MAPK pathway in the hippocampus. Noteworthy is that short-term and long-term memory use parallel but largely independent biochemical systems in the hippocampus involving ERK (Izquierdo et al., 1999; Izquierdo et al., 2002; Rosatto et al., 2003).

One study (Johnston \& Rose, 2001) concluded that inhibitory avoidance in the 1-day old chick apparently depends on BDNF but not NGF. Izquierdo et al. (2002) commented on discrepancies between metabolic changes related to inhibitory avoidance in adult rodents and in the day-old chick. A problem with the latter is that the animals were tested when they were twice the age that they were upon training.

\section{GENE EXPRESSION AND PROTEIN SYNTHESIS}

For years, memory consolidation of many tasks has been known to require protein synthesis in the hippocampus. Matthies (1989) demonstrated that RNA and protein synthesis occurs twice after a training session, first shortly after acquisition and then again 3 to $6 \mathrm{~h}$ later, and that both 'waves' are necessary for consolidation. This point was recently re-examined by Igaz et al. (2002), who found that not only protein synthesis but also gene expression is needed at those two critical periods. The authors used the time-honored protein synthesis inhibitor, anisomycin, and two different inhibitors of RNA polymerase II, DRB (5,6dichloro-1- $\beta$-d-ribofuranosyl benzimidazole) and $\alpha$-amanitin introduced into the hippocampus at different times after training at doses previously found to inhibit protein synthesis and gene expression effectively, respectively.

Certain authors have observed the effects of actinomycin D on memory, ascribing them to the inhibition of gene expression. Although such inhibition is an effect of the drug, it was shown many years ago that actinomycin D causes large 
necrotic lesions in the brain areas into which it is injected (Wetzel et al., 1976) and therefore is not recommended. DRB and $\alpha$-amanitin are to be preferred. Here we will ignore papers involving localized microinfusions of actinomycin $\mathrm{D}$, for obvious reasons.

Single-based gene studies provide evidence for the involvement of certain genes in different stages of the acquisition and consolidation of one-trial forms of fear conditioning. The list includes c-fos (Cammarota et al., 2000), BDNF (Hall et al., 2000; Alonso et al., 2002), zif268 (Hall et al., 2000), and C/EBP (Taubenfeld et al., 2001). A number of recent papers have focused attention on gene profiling using cDNA arrays. Fear conditioning increases the expression of several genes in the hippocampus, including those coding for $\alpha$-CaMKII, protein kinase B, ERK2, syntaxin 1A, mGluR7, dopamine receptor $1 \mathrm{~A}$, the neurotrophic receptor TRKB, and the synaptic protein homer (Igaz et al., 2004) nurr-1, $\alpha$-actinin, and 16c8 (Ressler et al., 2002). Water maze learning increases or decreases the expression of a host of other genes (Cavallaro et al., 2002). The results are somewhat irregular and different authors have found that the activation of different genes depends on the task and on the time at which gene expression is measured. This field is clearly in its beginnings, and the arrays used so far are not sensitive enough to detect subtle and possibly important changes.

The mapping of areas and species in which learning is associated with protein synthesis (and/ or sensitivity to anisomycin) has been enlarged in recent years. Auditory discrimination in gerbils is sensitive to anisomycin given into the auditory cortex (Kraus et al., 2002). The early consolidation of lever pressing for food is blocked by anisumycin given into the nucleus accumbens (Hernández et al., 2002). The inhibition of monoADP-ribosylation prevents the long-term consolidation of one-trial avoidance in day-old chicks (Edwards \& Rickard, 2002). Protein synthesis in the brain of the medaka fish is necessary for fear conditioning (Eisenberg et al., 2003).

Time windows of memory sensitivity to anisomycin, long known in mammals, have just been described in the sea slug Hermissenda: these time windows are different (Epstein et al., 2003) and differ from those of hippocampal LTP (Izquierdo \& Medina, 1997) which, in turn, differ from those of the hippocampus in consolidation (Matthies, 1989; Rose, 1995; Igaz et al., 2002). To begin with, in Hermissenda, the waves of protein synthesis are multiple and quicker; in LTP the protein synthesis wave appears to be just one. This observation further illustrates the differences between consolidation mechanisms across species and brain areas, and between consolidation mechanisms and LTP (Izquierdo \& Medina, 1997; Izquierdo \& McGaugh, 2000; Izquierdo et al., 2002).

Hensbroek et al. (2003) have now reported that spatial, contextual and working memory, all known to depend on the hippocampus, are unaffected by the absence of mossy fiber LTP. The mossy fiberCA3 connection is the gateway to the participation of CA1 and its projections in memory (Izquierdo \& Medina, 1997). Gone are the days in which LTP and memory were used as synonyms. Both reflect neural plasticity, but each type of LTP and each form of learning involves mechanisms of its own; some may be similar, others clearly are not. Actually, to be effective certain mechanisms that are crucial for memory formation, like those in the entorhinal cortex and elsewhere, probably have to be different from those of LTP (Ardenghi et al., 1997; Rosatto et al., 2003).

Extinction also requires protein synthesis and gene expression in selected brain structures:

- the hippocampus and the basolateral amygdala for fear conditioning (Vianna et al., 2001, 2003a,b), and

- the basolateral amygdala (Bahar et al., 2003) and the insular cortex (Berman \& Dudai, 2001) for conditioned taste aversion. 
Peripherally administered anisomycin is sufficient for the inhibition of memory consolidation but not necessarily for the inhibition of extinction (Lattal \& Abel, 2001), suggesting that the need for protein synthesis is higher in consolidation than in extinction (Vianna et al., 2003). Different from consolidation, extinction needs just one peak of gene expression and protein synthesis at the time of the first test trial without reinforcement; $3 \mathrm{~h}$ later, DRB and anisomycin are ineffective (Vianna et al., 2003).

Sometimes the infusion of anisomycin into the amygdala (Nader et al., 2000; Nader, 2002), into the hippocampus (Vianna et al., 2001; Debiec et al., 2002), or systemically (Milekic \& Alberini, 2002) at the time of retrieval can hinder retrieval in a subsequent test session. This phenomenon is not always seen (Vianna et al., 2001), but sometimes is seen using PKA or ERK inhibitors that are given in the hippocampus (Szapiro et al., 2003). Such interference has been attributed to the reconsolidation of the original memory by presenting the CS alone. The phenomenon is, as mentioned, not always reproducible and has been denied by certain authors (Myers \& Davis, 2002). Every time that behavioral testing was carried out beyond the second test, a recovery from the retrieval dip of the second test and an inhibition of extinction was observed; so the dip might be just a performance effect (Vianna et al., 2001; Szapiro et al., 2003; Vianna et al., 2003; Lattal \& Abel, 2004). The observation that retrieval makes memory labile and susceptible to change by, for example, the presentation of novelty (Izquierdo et al., 2000, 2003) or, as lawyers have known for centuries, a leading question, does not necessarily imply reconsolidation but rather a new consolidation process incorporating new data into prior memory. The effect of novelty on retrieval was studied pharmacologically and biochemically. The effect depends on PKA and ERKs (Viola et al., 2000). Further studies are desirable on the purported reconsolidation process involving the use of drugs or other variables that may effectively enhance responses in subsequent tests. So far, the postulation of reconsolidation in its present form (e.g., Nader, 2002) resides only in the inconstant effect of anisomycin given at the time of the first of two retention tests on performance in the second test but not in subsequent tests (Vianna et al., 2001; Lattal \& Abel, 2004). This evidence is not sufficient to support the notion implied by the word 'reconsolidation'.

Exactly which proteins are synthesized in the two peaks that follow the original training or in the single peak that is needed for extinction is not known. Evidence obtained in many studies after one-trail avoidance in the day-old chick (Rose, 1995) and in a similar and other tasks in rodents (Sandi et al., 2003) indicate that glyco- and glycosialo-proteins related to cell adhesion are synthesized by neurons that have recently participated in memory formation, apparently also in two waves. One of the best-known cell adhesion proteins whose synthesis is increased post-training and which is necessary for long-term consolidation is the neural cell adhesion molecule (NCAM) (Rose, 1995). The NCAM has been recently reported to be an alternative signaling receptor for ligands of the GDNF (glial cell line-derived neurotrophic factor) family (Paratcha et al., 2003). The GDNF is involved in neurite branching and regeneration, both of which are believed to play a role in long-term memory (Geinisman et al., 2001). The exact role of GDNF in learning and memory, however, has not been investigated.

\section{ENZYME INHIBITORS AND CRITICAL PERIODS FOR PROTEIN SYNTHESIS}

The two peaks of gene expression and protein synthesis necessary for consolidation and the peak necessary for extinction are accompanied by enhanced activity of PKA and by increased levels of the phosphorylated form of the constitutive 
transcription factor, CREB (Bernabeu et al., 1997; Taubenfeld et al., 1999). Simultaneously with those peaks of activity, memory becomes especially sensitive to PKA and ERK (MAPK) inhibitors in the hippocampus (see Izquierdo \& McGaugh, 2000). The CREB protein is a substrate of PKA, of the ERK pathway (which also becomes activated at the time of the second peak (Cammarota et al., 2000), and of other kinases (Wu et al., 2001). When phosphorylated at ${ }^{133}$ Ser, CREB triggers the transcription of various genes, some of which are believed to be important for the fixation of long-term memory, as well as for the persistence of LTP beyond 3 or 4 hours (see Izquierdo \& McGaugh, 2000). Behavioral training in one-trial avoidance increases p-CREB levels not only in the nucleus of hippocampal pyramidal cells (Bernabeu et al., 1997) but also in synaptic mitochondria (Bevilaqua et al., 2001). In the nucleus, downstream of CREB, the CCAAT enhancerbinding protein (C/EBP) is also induced; it colocalizes with p-CREB and accompanies longterm memory consolidation (Taubenfeld et al., 2001), for which it is also necessary. A recent intriguing paper suggests that the ERK pathway might be correlated with the temporal integration of stimuli in the hippocampus (Selcher et al., 2003).

In areas other than the hippocampus, the ERK inhibitors, U0126 and PD098059, and the PKA inhibitors, Rp-cAMPs and KT-5720, are amnesic as well, but post-training intervals are different from those in the hippocampus (Ardenghi et al., 1997; Rosatto et al., 2003). Such disparity strongly suggests that PKA and ERK in other structures (basolateral amygdala, entorhinal cortex, posterior parietal, anterior cingulate cortex) are as necessary for memory consolidation as they are in the hippocampus but follow in them a time course of activation that is quite different from that observed in the hippocampus, and also quite different from that observed in LTP. A dual peak of PKA activity, ascertained by the action of the inhibitor, Rp-cAMPs, and the stimulant, Sp-cAMPs, has been described in a form of aversive learning in the crab Chasmagnatus; the timing of the peaks is different from that of avoidance learning in mammals (Locatelli et al., 2002).

The role of ERKs in the hippocampal circuitry previously described for one-trial avoidance (Walz et al., 1999a,b) was now observed in an object recognition task (Kelly et al., 2003) and in longterm spatial memory (Hebert \& Dash, 2002). In one-trial avoidance, the activity of p42 and p44 increases both after training (Cammarota et al., 2000; Alonso, 2002) and after testing (Szapiro et al., 2000).

Two other enzymes of the MAPK family have also been investigated-the c-Jun N-terminal kinase (JNK), and p38MAPK. The intra-CA1 infusion of SP600125, the newly developed inhibitor of JNK, at a dose that reduces c-Jun phosphorylation without affecting ERK $1 / 2$ or p38MAPK activity, enhances short-term memory but blocks long-term memory formation and the retrieval of one-trial avoidance in rats (Bevilaqua et al., 2003). Aside from indicating a multiple role of JNK in memory processes, the results further underline the dichotomy between short-term and long-term memory for this task (Izquierdo et al., 2002). In contrast, the post-training intrahippocampal infusion of the specific p38MAPK inhibitor, SB203580, inhibits both short-term and long-term memory formation of this task; the inactive analog, SB202474 has no effect (Alonso et al., 2003). A role for the p38 MAPK enzyme in the cerebellar vermis in the acquisition of eye-blink conditioning in the rabbit has also been described (Zhen et al., 2001).

Both PKA and the ERK are necessary in CA1, the basolateral amygdala, the entorhinal cortex, the posterior parietal, and the anterior cingulate cortex for the retrieval of one-trial avoidance (Barros et al., 2000). This requirement indicates that retrieval is not the sole province of the hippocampus, as was once believed (Barros et al., 2003), and that it is far from a passive event. Retrieval requires 
different glutamate receptors, as mentioned above, and two major signaling pathways. A deregulation of the ERK pathway in Alzheimer disease has been proposed to be at the root of the pathogenesis of this disease (Zhu et al., 2003).

Protein kinase A and ERK are also necessary in the hippocampus (Szapiro et al., 2003) and the basolateral amygdala (Lu et al., 2001) for the generation of the extinction of fear conditioning at the time of the first unrewarded retrieval test. So are intact NMDA receptors (Falls et al., 1992; Szapiro et al., 2003). In addition, CaMKII is necessary in the hippocampus for the extinction of one-trial avoidance (Szapiro et al., 2003); in the basolateral amygdala, the role of CaMKII in extinction has not been investigated.

Concerning the role of amygdalar PKA activity in consolidation and extinction, two papers from the same laboratory suggest that in conditioned-taste aversion, things may be different from what has been described in one-trial avoidance in the rat, both concerning extinction (which is enhanced by Rp-cAMPS) and short-term memory, which is unaffected by that drug (Koh et al., 2003). As conditioned taste aversion appears to be rather atypical, in the sense that it does not seem to have the same molecular requirements for acquisition and extinction as do other aversive tasks, both in the insula (Berman \& Dudai, 2001) and in the amygdala (Bahar et al., 2003), a more thorough and systematic study of its neural and molecular circuitry is desirable.

The role of other enzymatic pathways in memory has also been investigated with the use of localized infusions of inhibitors. The involvement of guanylyl cyclase and protein kinase $G$ in memory formation of one-trial avoidance in the day-old chick has been demonstrated (Edwards et al., 2002). The results of that study agree with a similar observation in the hippocampus obtained years ago in one-trial avoidance in rats (Bernabeu et al., 1996; Izquierdo \& Medina, 1997). A role for cyclin-dependent kinase $5(\mathrm{Cdk})$ in contextual fear conditioning is suggested by the observation that the infusion of its antagonist, butyrolactone I, into the lateral septum or the hippocampus profoundly impairs memory of the task; importantly, a single injection of the inhibitor into either the lateral septum or the hippocampus blocks Cdk over the entire lateral septum and hippocampus (Fischer et al., 2003). This blockade appears to validate the use of localized brain infusions of drugs as indicative of their action over large portions of the infused structure rather than only in the infusion site (see Izquierdo et al., 1999).

The involvement of hippocampal phosphatidylinositol 3-kinase (PI3K) in fear conditioning has been demonstrated in the amygdala (Lin et al., 2001), where it also blocks LTP, and in the hippocampus (Barros et al., 2001). In the hippocampus, the PI3K inhibitor LY294002 blocks acquisition, short-term memory formation, longterm memory formation, and retrieval over a wide range of doses. These findings appear to point to the PI3K pathway as one of the most critical for learning and memory and it certainly deserves further study. The PI3K pathway is also linked to the recently demonstrated participation of calcineurin in memory formation (Lin et al., 2001; Lin et al., 2003).

The molecular pharmacology of consolidation of non-associative learning has been little studied over the years, but the results are quite clear. Long-term habituation learning does require NMDA receptors, protein synthesis, and signaling pathways in the rat hippocampus (Vianna et al., 2000), and all those plus non-AMPA receptors and protein phosphatase activity in the abdominal ganglion of Aplysia (Ezzedine \& Glanzman, 2003).

\section{PHARMACOLOGY OF THE UBIQUITIN PROTEASOME SYSTEM}

The ubiquitin-proteasome system hydrolyses residues of proteins-such as IK B, the regulatory 
subunit of PKA, and the $\beta$-amyloid peptide - that have been used in recent cell activity (Bloom et al., 2003) and protects against oxidative stress (López-Salon et al., 2003). This system is defective in the brain of victims of Alzheimer disease (López Salon et al., 2000). Intracellular protein inclusions in Alzheimer disease contain a variant of ubiquitin, $U B B+1$, which while still protective against oxidative stress, blocks proteasome $26 \mathrm{~S}$ and is defective for most other cellular functions (Hope et al., 2003).

Recently, the ubiquitin-proteasome system in the hippocampus of rats has been found to be essential for the memory consolidation of one-trial avoidance. Two specific proteasome inhibitors, lactacystin and proteasome inhibitor I, given 1, 4, or $7 \mathrm{~h}$ post-training, block memory consolidation of this task completely. Hours after training, inhibitory avoidance training results in increased 26S proteasome activity and decreased IK B in the hippocampus. These findings indicate that protein degradation by the ubiquitin-proteasome system in the several hours following acquisition is as necessary for long-term memory formation as is protein synthesis (López-Salón et al., 2001). No doubt, this cell system is one of the most interesting to be studied in relation to its precise function in memory formation and memory dysfunctions.

\section{MEMORY MODULATORY MECHANISMS IN THE BRAIN}

\section{GABA $_{\mathbf{A}}$ mediated mechanisms}

The major brake for the installment of memory consolidation is provided by $\mathrm{GABA}_{\mathrm{A}}$ receptors at the various regions of the brain where memories are made (Izquierdo et al., 1992). Picrotoxin and bicuculline have been known for years to facilitate memory formation (for references, see Izquierdo et al., 1992; Izquierdo \& McGaugh, 2000; McGaugh
\& Izquierdo, 2000). Picrotoxin, which blocks the chloride channel of $\mathrm{GABA}_{\mathrm{A}}$ receptors, facilitates extinction as well (McGaugh et al., 1990). Agents that enhance or mimic the action of GABA disrupt memory. Tiagabine, which inhibits the transport of GABA away from the synaptic cleft, impairs spatial learning (Schmitt \& Hiemke, 2002). Muscimol given into the hippocampus impairs contextual retrieval of fear memory after extinction (Corcoran \& Maren, 2001).

A few years ago, endogenous benzodiazepinelike molecules were described in the brain (De Blas \& Sangameswaran, 1986), and the memoryenhancing effect of flumazenil, an antagonist of brain benzodiazepine receptors at the $\mathrm{GABA}_{\mathrm{A}}$ receptor complex was described (see Izquierdo \& Medina, 1991). Aside from its use for a prompt recovery from hepatic coma, in which endogenous and exogenous benzodiazepines are poorly metabolized (Basile, 1993), flumazenil has either not found much therapeutic application or has not been sufficiently studied in this connection. Flumazenil potentiates the reversal by ondansetron of scopolamine amnesia in spatial learning in rats (Diez-Ariza et al., 2003). In humans, the drug reverses midazolam-induced sedation (Girdler et al., 2002) and enhances repetition adaptability, believed to be downregulated by widespread GABAergic inhibitory systems (Stephenson et al., 2003). The importance of the GABAergic mechanism is illustrated by the observation that a pretraining treatment with systemic midazolam prevents the post-training memory facilitation caused by adrenaline, naloxone, dexamethasone, and glucose-four agents having very different modes of action (Quevedo et al., 2002).

Because of the widespread nature of memory inhibition by $\mathrm{GABA}_{\mathrm{A}}$ receptors (Brioni, 1993) and its clear physiological importance (Izquierdo et al., 1992), and because of the relative lack of side effects, it should be interesting to study the effect of flumazenil in more instances of human memory. Possibly the memory deficit induced by diazepam 
is stronger than that induced by scopolamine: the memory-enhancing drug, oxiracetam, can prevent the latter but not the former (Hlinak \& Krejci, 2002).

\section{Monoamines}

The role of dopamine-D1, $\beta$-noradrenergic, and 5HT-1A receptors in the hippocampus, basolateral amygdala, entorhinal and parietal cortex in consolidation (Ardenghi et al., 1997; Bevilaqua et al., 1997; Izquierdo \& McGaugh, 2000; McGaugh \& Izquierdo, 2000; McIntyre et al., 2003; Wang \& $\mathrm{Li}, 2003$ ) and retrieval (Barros et al., 2001) appeared settled until very recently. In general, dopamine-D1, $\beta$-noradrenergic, and muscarinic cholinergic receptors have an enhancing effect in those structures, and 5HT-1A receptors have an inhibitory action on memory variables. Recent research, however, has added significant data pointing both to the involvement of other receptors and of other systems.

Hale and Crowe (2002) found that the D3 dopamine receptor agonist, 7-OH-DPAT, disrupts memory consolidation of one-trial avoidance in the day-old chick. Bernaerst and Tirelli (2003) reported that the D4 receptor agonist, PD168077, facilitates memory consolidation of a similar task in mice, which in addition attenuates the amnesic effect of 7-HO-DPAT. Apomorphine is a drug traditionally used to mimic dopamine effects; recently its main metabolite was found to have effects on memory that are be very different from those of the parent compound (Picada et al., 2002)

In $\mathrm{CA} 1$, dopamine $\mathrm{D} 1$ receptor activation at 3 to $4 \mathrm{~h}$ after training enhances memory consolidation through an indirect stimulation of PKA via adenylate cyclase (Ardenghi et al., 1997), similar to what occurs 3 to $4 \mathrm{~h}$ after the induction of hippocampal LTP. This action is shared on memory consolidation of one-trial avoidance in rats by $\beta$-noradrenergic receptor stimulation, and both converge toward an enhancement of CREB phos- phorylation and protein synthesis in the hippocampus (Izquierdo \& Medina, 1997). Recently, Straube and Frey (2003) found that $\beta$-noradrenergic receptor activation in freely moving rats 3 to $4 \mathrm{~h}$ after induction helps to maintain LTP. The use of strong and repeated tetanic stimulation can compensate for the loss of $\beta$-noradrenergic activation because in the behaving rat, a stronger training stimulus can compensate for the lack of post-training modulatory influences. Norepinephrine infused into the basolateral amygdala of rats enhances the consolidation of two different forms of contextual fear conditioning (LaLumiere et al., 2003), as has been known in one-trial avoidance and other tasks (see McIntyre et al., 2003).

The enhancing effect of $\beta$-adrenoceptors on memory consolidation has usually been attributed to $\beta_{1} / \beta_{2}$ receptors. Using three different $\beta_{3}$ receptor agonists, Gibbs and Summers (2001a) found in the day-old chick that in one-trial avoidance, $\beta_{3}$ receptors are also involved. In another paper, the same authors (Gibbs \& Summers 2001b) found that $\alpha_{1}$ receptors inhibit memory consolidation, and, in a third paper (Gibbs \& Summers, 2002c), found that $\alpha_{2}$ receptors in the basal ganglia favorably modulate the enhancing influence of $\beta_{1}$ and $\beta_{2}$ receptors on consolidation. These complex interactions among adrenoceptors should also be studied in mammals. A significant correlation was found between plasma free 3-methoxy-4-hydroxyphenylglycol, a noradrenaline metabolite, measured after encoding an emotionally arousing story shown in slides, and long-term retention of the story (Southwick et al., 2003).

Similar complexities have been found to occur with $5 \mathrm{HT}$ receptors. As mentioned, the activation of 5HT1A receptors in many places in the brain usually enhances consolidation and retrieval. Many other 5HT receptors are found in many places in the brain, however, and the effect of 5HT release or of the infusion of diverse 5HT-receptor agonists and antagonists can have several different effects, which can physiologically interact in many 
ways. Thus, the post-training infusion of $5 \mathrm{HT}$ into the dorsal ventral striatum causes amnesia for onetrial avoidance in rats but has no effect when given into the dorsal ventral striatum (Prado-Alcalá et al., 2003). Acute tryptophan depletion leads to a transient but marked fall of 5HT contents in humans. Such depletion impairs episodic recall with no effect on the magnitude or the topography of the neural correlates of retrieval, as measured by event related potentials in healthy human volunteers (McAllister-Williams et al., 2002). This effect is in direct contradiction to a previous report from our group, in which we found no effect of acute tryptophan depletion on memory (Shansis et al., 2000), and explaining why is difficult. in our laboratory, acute phenylalanine and tyrosine depletion, which inhibits catecholamine synthesis, did cause a transient memory deficit in humans (Grevet et al., 2002).

Meneses $(2001,2002)$ thoroughly investigated the role of 5HT1B and 5HT2A,B receptors in memory consolidation by examining the effect of diverse agonists and antagonists of these three receptor types and their interactions with other drugs (dizolcipine, scopolamine, and others). A partial agonist at 5HT4 receptors, when given systemically together with an anti-cholinesterase agent, enhances place and object recognition in rats (Lamirault et al., 2003). To say the least, the picture concerning the possible role of 5HT1B, $5 \mathrm{HT} 2 \mathrm{~A}, \mathrm{~B}$, and 5HT4 receptors in memory is complex, but their interactions are important inasmuch as they indicate that in situations like clinical depression, in which abnormalities of 5HT-containing terminals are thought to occur (McAllister-Williams et al., 2002), a variety of memory changes and disturbances can be expected.

\section{Histamine}

Long-standing evidence indicates that brain histamine plays a role in the modulation of memory consolidation via $\mathrm{H} 1$ and $\mathrm{H} 2$ receptors
(De Almeida \& Izquierdo, 1986, 1988). Recent research suggests that such modulation involves $\mathrm{H} 3$ receptors too, but the data so far are unclear. The $\mathrm{H} 3$ receptor antagonist, thioperamide, given systemically causes time-dependent retrograde memory facilitation, with no influence on retrieval, and in addition reverses the amnesic effect of scopolamine (Orsetti et al., 2001). For some time peripheral histamine has been known to be uninvolved in memory modulation (Almeida \& Izquierdo, 1988), so presumably the role of $\mathrm{H} 3$ receptors must be central. A different report, however, shows that activation of $\mathrm{H} 3$ receptors in the rat basolateral amygdala by $\mathrm{R}$ - $\alpha$-methylhistamine or immepip improves the consolidation of fear memory and enhances acetylcholine release, measured by microdialysis (Cangioli et al., 2002). The authors had previously reported that the $\mathrm{H} 3$ antagonists, ciproxifan, clobenpropit, and thioperamide given into the basolateral amygdala decrease spontaneous acetylcholine release and enhance memory consolidation (Passani et al., 2001). Such a decrease points to a possible central site of action of $\mathrm{H} 3$ ligands and endorses the possibility that histamine and cholinergic mechanisms can interact in memory modulation. This observation is in direct contradiction to the data with systemic thioperamide, however. Possibly the latter could act on a set of $\mathrm{H} 3$ receptors in the brain elsewhere than in the amygdala. A role of peripheral histamine in memory modulation was discarded years ago by the lack of effect of the peripheral histamine releaser, 48/80 (Almeida \& Izquierdo, 1988).

\section{Cholinergic systems}

The role of central cholinergic mechanisms in memory has attracted much attention over the past 30 years. In fact, decades ago the amnesia induced by scopolamine was often taken as a model for Alzheimer disease, and there was or is a cholinergic hypothesis of Alzheimer disease and/or of 
dementia in general. Recent imaging (e.g., El Fakhri et al., 2003; Karas et al., 2003) and neuroanatomic findings (Hyman et al., 1990; Arriagada et al., 1992) point, rather, to a pathology beginning in the medial temporal lobes in Alzheimer disease and extending to the frontal and parietal cortex. Studies on the biochemistry of Alzheimer disease now center on amyloid and tau protein dysfunctions (Hardy, 2003; Davis \& Laroche, 2003), sometimes in relation to ubiquitin changes (LópezSalón et al., 2000). The more recently developed treatments of the disease explore new targets beyond cholinergic systems like the dopamine D2 receptor (Kemppainen et al., 2003), vaccines (Janus, 2003; Sergeant et al., 2003), and antibodies against $\beta$-amyloid (Hock et al., 2003). It is beyond the purpose of this review to analyze such treatments; for such an analysis, the reader is referred to the excellent recent review by Davis and Laroche (2003).

Enough links exist, however, between brain cholinergic muscarinic systems and Alzheimer pathology to warrant continued investigation of the former in relation to both memory consolidation and Alzheimer disease. Acetylcholinesterase inhibitors are still viewed by many as the drugs of choice for the treatment of Alzheimer disease (see Giacobini, 2003), and they play a role in the metabolism of the amyloid-precursor protein (Pakaski \& Kasa, 2003). Imaging studies have measured brain acetylcholinesterase in Alzheimer patients and found a significant reduction in the amygdala (-33\%), the hippocampus $(-14 \%)$, and the neocortex $(-20 \%)$; the amygdala is known to be a major projection of the brain cholinergic system (Shinotoh et al., 2003). Increased Alzheimer pathology in Parkinson disease is related to the use of antimuscarinic drugs in the latter (Perry et al., 2003). It is interesting to read the twin articles by Francis (2003) and Giacobini (2003) on the role of glutamatergic and cholinergic transmission in Alzheimer disease, respectively.
The main source of brain acetylcholinecontaining fibers is the nucleus basalis mangocellularis of Meynert, whose stimulation can be used as an US (McLin et al., 2003). Lesions of this nucleus impair the cortical plasticity associated with skill learning (Kilgard, 2003; Conner et al., 2003), hereto associated with extracortical processes. In rats, new acetylcholinesterase inhibitors were found to reverse the spatial cognitive impairment brought about by chronic cerebral hypoperfusion (Xu et al., 2002) or scopolamine (Chen et al., 2002) and to enhance place and object recognition (Lamirault et al., 2003). There might be a link between histamine $\mathrm{H} 3$ receptors (see above) and the cholinergic system in the nucleus basalis of Meynert: an H3 receptor blocker given into that nucleus improves place recognition memory (Orsetti et al., 2002).

Systemically administered atropine impairs the retrieval even of highly consolidated one-trial avoidance in mice (Boccia et al., 2003). When given in the hippocampus, the amygdala, or the entorhinal, posterior parietal, or anterior cingulate cortex, scopolamine blocks and oxotremorine enhances the retrieval of one-way avoidance (Barros et al., 2001). More is known about the brain map of cholinergic modulatory mechanisms for retrieval than for consolidation. In comparison, more is known about the muscarinic receptor types involved in consolidation, at least in the rat hippocampus. In the same task, studies using selective muscarinic toxins have revealed that M1 and M4 are involved (Ferreira et al., 2003).

Post-training intra-amygdala scopolamine impairs the conditioned place preference brought about by food or by amphetamine (Schroeder \& Packard, 2002) and of avoidance learning in an elevated T-maze, in which anxiety is the reinforcement (De-Mello \& Carobrez, 2002).

Perhaps the most creative experiments concerning the acetylcholine regulation of memory have been produced by Gold (2003) and his group. 
The authors centered their approach in measuring acetylcholine release by microdialysis in different areas of the brain in relation to memory tasks known to be dependent on those areas or on others. The investigators found that the diencephalic damage caused by pyrithiamine-induced thiamine deficiency reduced the release of hippocampal acetylcholine during spontaneous alternation, a task known to depend on the hippocampus (Savage et al., 2003). Gold and colleagues observed changes in the pattern of hippocampal and striatal acetylcholine release when rats in a cross maze were switched from learning on the basis of place (using distant cues) to learning on the basis of response (choosing between turning left or right to find the food). Learning in the space mode was initially accompanied by a larger release of the transmitter in the hippocampus than in the striatum (Chang \& Gold, 2003).

McIntyre et al. (2002) found that acetylcholine release in hippocampus correlates negatively with good performance in an amygdala-dependent task (food-conditioned place preference), indicating competition between memory systems. Subsequently, McIntyre et al. (2003) observed cooperation between memory systems: acetylcholine was increased in the amygdala during spontaneous alternation, a classic hippocampus-dependent task. The switches-competition and cooperation between memory systems tasks-illustrate the complex interactions that can take place among these systems (Gold, 2003).

The medial septal nucleus is a site of action for the memory-stimulating effects of oxotremorine and the amnesic effect of scopolamine (see Izquierdo et al., 1992). Pregnenolone given into this area increases acetylcholine release in the hippocampus and improves recognition memory in rats (Darnaudery et al., 2003).

Working memory was hitherto supposed to be regulated mainly by the prefrontal cortex (Goldman-Rakic, 1996) and, at least in part, by the hippocampus (Olton, 1985). Two recent papers using cholinergic muscarinic agonists/antagonists have clearly shown that a mechanism involving such receptors regulates working memory in the basolateral amygdala (Beninger et al., 2001; Barros et al., 2002).

A very interesting study showed that scopolamine induces a time- and dose-dependent recovery of an extinguished one-trial inhibitory avoidance response, even 1 month after training (Roldán et al., 2001; see also Prado-Alcalá, 1995). This result of course supports the idea that extinction is a new learning that does not erase the original response, and in addition provides the first pharmacological clues about the transmitters involve in this recovery.

The purportedly antiepileptic GABAergic compound, gabapentin, which was recently shown to be anxiolytic (De-Paris et al., 2003), was found to improve memory consolidation in mice through a central muscarinic mechanism. Its memoryenhancing effect was enhanced by physostigmine but not by neostigmine and prevented by atropine but not by methylatropine, mecamylamine, or hexamethonium (Boccia et al., 2001). The effect was not found in rats using similar or higher doses of gabapentin (De-Paris et al., 2000).

The November 2003 issue of Neurobiology of Learning and Memory was dedicated to acetylcholine and brain functions. Of the many interesting articles therein, perhaps the most heuristic are those by Gold (2003), Power et al. (2003), and Weinberger (2003). The latter is of particular importance because it supports a role for central nicotinic cholinergic mechanisms in the expansion of auditory cortical auditive receptive fields upon Pavlovian conditioning. In the same issue, Disterhoft and Oh (2003) produce good evidence that muscarinic receptors in the hippocampus positively modulate their excitability in trace eyeblink conditioning. Rogers and Kesner (2003) show a role of muscarinic receptors in the encoding and retrieval of a modified Hebb-Williams maze. 


\section{The endocannabinoid system}

The discovery, first of receptors for cannabinoids and then of endogenous ligands for these receptors, spurred much interest in the behavioral effects of such compounds in recent years. The main endogenous receptor for the cannabinoids is called CB1 and is widely distributed all over the brain. The main endogenous ligand is anandamide (see Wilson \& Nicoll, 2002; Vianna et al., 2003 for references), but there are others, including one that is antagonistic at the CB1 receptor (Porter et al., 2002). The deleterious effects of cannabinoids on learning and memory processes was first described by Orsingher and Fulginiti in 1970, and recently confirmed by Mishima et al. (2001).

The deficit of spatial learning caused by delta 9-tetrahydrocannabinol is blocked by the specific CB1 antagonist, SR241716A (Da \& Takahashi, 2002). Anandamide impairs memory consolidation of one-trial avoidance in mice; pre-exposure to the apparatus reduces the effect. The drug has no effect upon retrieval when given before testing (Costanzi et al., 2003).

The most important recent finding concerning the endogenous cannabinoid system and memory is the demonstration that this system, probably in the basolateral amygdala, controls the extinction of aversive conditioned responses in the rat (Marsicano et al., 2002). This aspect should now be studied in relation to the signaling pathways found to regulate extinction in the amygdala and elsewhere (see Vianna et al., 2003a, b). The amygdala is characterized by a large presence of CB1 receptors, which appear to be in control of local GABAergic transmission (Katona et al., 2001).

The CB1 cannabinoid system has also been proposed to play a role in the endogenous defense against excitotoxocity (Marsicano et al., 2003), in the induction of LTP (Carlson et al., 2002), and in the mediation of retrograde signaling in the hippocampus (Wilson \& Nicoll, 2001).

\section{Bombesin}

One paper shows that the intrahippocampal infusion of RC-3095, the bombesin/gastrin-releasing peptide antagonist, impairs inhibitory avoidance in rats (Roesler et al., 2003). The drug was effective when given immediately or $2 \mathrm{~h}$ after training. This finding suggests the presence of receptors for bombesin in the hippocampus, and that these are able to regulate memory consolidation for a long time after training.

\section{Memory modulation by glucose}

Memory modulation by glucose was discovered by Gold (1986) and then investigated by his group and by many others (eg. Sunram-Lea et al., 2002; Metzger \& Flint, 2003). More recently, Gold's group when measuring extracellular brain glucose observed that the level of extracellular fluid glucose in the brain is much lower than previously thought and fluctuates widely across brain areas during testing. The extracellular glucose levels decrease by $30 \%$ in the hippocampus and increase by $9 \%$ in the striatum during spontaneous alternation (McNay et al., 2001). Further, extracellular hippocampal glucose levels decrease with aging: at the age of 3 months in rats, those levels tend to accompany circulating glucose levels but reverse at the age of 24 months (McNay \& Gold, 2001).

Systemic or intra-amygdala glucose injections facilitate onset of the extinction of drug-induced conditioned reward (Schroeder \& Packard, 2003). In the day-old chick inhibitory avoidance model, glucose enhances, and the glucose-uptake inhibitor 2-deoxyglucose disrupts memory consolidation. Using $\beta 2$ and $\beta 3$ adrenoceptor blockers, Gibbs and Summers (2002) concluded that the latter receptor subtype could facilitate glucose uptake by brain cells at the time of consolidation. Talley et al. (2002) observed that vagotomy attenuates the enhancement effect of glucose on spontaneous 
alternation. This point is of interest on two counts. First, the effect of glucose on that task, believed to be regulated almost exclusively by the hippocampus. Second, the suggestion that the glucose effect can be mediated by vagal afferents, such as studied 45 years ago in connection with the regulation of blood pressure (Izquierdo et al., 1959).

\section{STRESS AND MEMORY}

Memory consolidation and retrieval have been known for a long time to be regulated by circulating levels of stress hormones (Izquierdo, 1989). A lot of work has been done in the past 2 years on this topic. The epinephrine enhancement of human memory consolidation occurs through an interaction with arousal at the time of encoding (Cahill \& Alkire, 2003). Possibly other stress hormones like corticoids, adrenocorticotropin, vasopressin, $\beta$-endorphin (see Izquierdo, 1989) can act similarly. Long ago, Gold and McGaugh (1975) proposed that endogenous stress hormones modulate memory consolidation for experiences that induce their release. Subsequently, Izquierdo (1989) produced evidence showing that these substances actually induce a form of endogenous state dependency for the tasks that released them, or for the effect of their systemic administration.

Glucocorticoids have opposite effects on consolidation, which they regularly enhance, and on retrieval, which they consistently impair (Roozendaal, 2002; McAllister-Williams \& Rugg, 2002; Hsu et al., 2003). The consolidation effect is due to an interaction with a $\beta$-adrenoceptor mechanism in the basolateral amygdala involving activation of a cAMP/PKA system (Roozendaal et al., 2002). The action of glucocorticoids upon retrieval probably involves the hippocampus (Roozendaal et al., 2001; Jezek et al., 2002) with an involvement of the amygdala (Roozendaal et al., 2003) and is accompanied by reduced blood flow in the medial temporal lobe (de Quervain et al., 2003).

Whereas the influence of glucocorticoids or other stress hormones facilitates memory formation for traumatic or otherwise aversive experiences (Cordero et al., 2002), the influence of glucocorticoids at the time of retrieval prevents recall of such experiences and therefore protects from the possible development of post-traumatic stress disorder(s) (Schelling, 2002). Chronic and repeated stress causes hippocampal cell death from the actions of glucocorticoids at their receptors (Sapolsky, 2001); this exacerbation of local toxicity is not caused by apoptosis (Roy \& Sapolsky, 2002).

Stress experience and age determine the impairing or enhancing effects of stress and corticoids on retrieval (Yang et al., 2002). Recently we studied the effect of four different stress hormones, ACTH, adrenaline, vasopressin, and $\beta$-endorphin on the retrieval of one-trial avoidance in rats, measured at 1 day or at 3 to 19 months after training - that is, when both memory and animals were young, middle-aged, and old (Izquierdo et al., 2002). The animals were trained at the age of 3 months. When given before testing, all four drugs facilitated retrieval. The doses needed 1 day after training were lower than at 3 months. Between 6 and 9 months, the effect of the four hormones changed into a negative influence: all four depressed retrieval. Yet, in animals tested 12 to 19 months after training at the younger age, retrieval again became gradually more and more sensitive to the drugs, and at the oldest age (22 months) and training-test interval (19 months), retrieval was as sensitive to the facilitator effect of the hormones as it was at the age of 3 months. This finding suggests a strong bimodal response of retrieval mechanisms to age and/or training-test intervals and may be related to the higher emotionality and retrieval of emotional responses seen in the young and the old, as compared with middle-aged humans. 
Vasopressin has long been known to enhance both memory consolidation and retrieval in rodents (see above and Paban et al., 2003). The effect on consolidation has not always been reproduced in humans, as a recent failed attempt attests (Gais et al., 2002), making it somewhat different from other stress hormones (see Cahill \& Alkire, 2003).

\section{NON-CORTICOID-STEROID HORMONE EFFECTS ON MEMORY}

The effect of androgens and estrogens on memory has been comparatively little studied over the years. Recently, Johnston and Migues (2001) found a task- and time-dependent memory enhancement by dehydroepiandrosterone in a visual categorization task and in one-trial avoidance in the day-old chick. The substance is normally present in the chick brain, which makes the result even more interesting. Androgens given posttraining to ovariectomized rats enhance the memory of a Y-maze, inhibitory avoidance, and object recognition; the effect is unrelated to changes in affective behavior caused by the hormones (Frye \& Lacey, 2001).

In rats, estrogens quickly enhance visual and place memory in rats (Luine et al., 2003). The finding is consistent with that of Chen et al., (2002) who observed that the two antiestrogen agents tamoxifen and toremifene (widely used for the treatment of breast cancer) impair memory in appetitive and aversive several tasks in mice. It would be interesting to know whether the actions of estrogens on memory involve the recently described G-protein-coupled receptor implied in rapid signaling involving protein kinase $\mathrm{C}$ in the hypothalamus (Qin et al., 2003). Pregnenolone and other neurosteroids have been proposed to be biomarkers of 'cognitive aging' (Vallee et al., 2003). As mentioned above, pregnenolone acts on the medial septum to improve recognition memory (Darnaudery et al., 2002).

\section{STATE DEPENDENCY}

The concept of endogenous state dependency was formulated twenty years ago (Izquierdo, 1984, 1989). The hypothesis is based on the principle that the prevalence of neurohumoral and hormonal states at the time of retrieval similar to those that existed in the post-training period is a key factor in retention test performance. Numerous experiments have endorsed this proposal.

Recently, the concept was retaken by Colpaert and his group, who enlarged it to the point that, according to their formulations and supporting findings, mnesic states actually govern both normal and disordered memory (Colpaert et al., 2001). This notion would apply not only to opioidaddiction states (Bruins Slot et al., 2001) but also to the lack of full reversal of the amnesic effect of scopolamine by tacrine (Bruins Slot et al., 2003). This approach is interesting and it might explain the hitherto obscure aspects of memory retrieval.

To reexamine the recent proposal by Summers et al. (2003) of two consecutive processes in retrieval might be useful, in light of not only the concept of endogenous state dependency (Izquierdo, 1984; Colpaert et al., 2001) but also the findings on the molecular pharmacology of retrieval (Barros et al., 2000, 2001, 2003). Enough evidence might not be available to sustain the dual-process hypothesis of retrieval, which is a pity because the hypothesis is sound and worth further exploration.

\section{EXTINCTION: ITS THERAPEUTIC ROLE AND CAN IT BE ENHAN CED?}

Acquired fear is at the root of phobias, panic attacks, generalized anxiety, posttraumatic stress disorder, and at least some forms of depression, including that of bipolar disorders (Lee et al., 2002; Beckett, 2002; Rothbaum \& Schwartz, 2002). It thus appears as a therapeutic desideratum 
to inhibit conditioned fear in these patients. Extinction has been for 80 years the therapy of choice for the treatment of psychiatric problems caused by acquired fear (Cammarota et al., 2003; Paquette et al., 2003). Therapies involving extinction are sometimes called habituation, exposure, or flooding therapies, but in essence, all consist of repeated exposure to the stimuli that had been conditioned to represent fear by previous training, but now in the absence of reinforcement. Several sources of failure in the therapy of conditioned fear have been reported; these have been recently revised by Bouton (2002). Care must be taken to promote extinction and to avoid the reinstatement of the original fear (Cammarota et al., 2003).

Often extinction or exposure therapies are complemented by benzodiazepines, seen by some (Harris \& Westbrook, 1999) as extinction enhancers, or by other drugs, like propranolol, which has been used for years to attenuate anxiety at the time of retrieval or performance. Recently, a nonpharmacologic enhancement of extinction has been obtained in rats merely by increasing the time spent by the rats in the no-reinforcement situation. Animals were trained in a standard one-way inhibitory procedure, using a platform as the CS and a footshock delivered to a grid as the US. In extinction sessions, the footshock was not delivered; but instead of withdrawing the animal from the training apparatus, as is usually done (eg., Vianna et al., 2003), the animals were allowed to explore the grid freely for 30 seconds with no footshock. Under such conditions, extinction was stronger, and to reinstall the original conditioned response in a fifth extinction session, the animals required gene expression and protein synthesis: recovery of the original learning was blocked by DRB and anisomycin (Cammarota et al., 2003) as if the task were new (Igaz et al., 2002). Devising many ways in which such an enhanced exposure to the absence of the US can be applied to human therapy situations is possible.

\section{FINAL COMMENT}

Major advances have been made in the past 2 or 3 years on the biochemical pharmacology of memory, retrieval, and extinction. Nevertheless, we are still far a long away from understanding the intimate nature of memory, retrieval, and extinction. The key question of what memory consolidation, retrieval, and extinction really are about has not yet been answered. To show that one or other housekeeping neurotransmitter(s) or enzyme(s) are involved in consolidation, extinction or retrieval at different times is not the same as showing their intimate nature, as believed around 3 years ago. Studies on differential gene activation by learning tasks have so far been disappointing. The multitude of new findings in the area of the molecular mechanisms of memory might give us reasons to rejoice but not yet celebrate a genuine breakthrough.

We apologize to the authors of the perhaps many significant papers that came out during the past 2 or 3 years in the subjects reviewed and were not included here; but then, that is the lot of reviews. They are always bound to be incomplete.

\section{REFERENCES}

Alonso M, Bevilaqua LR, Izquierdo I, Medina JH, Cammarota M. 2003. Memory formation requires p38 MAPK activity in the rat hippocampus. Neuroreport 14: 1989-1992.

Alonso M, Vianna MR, Depino R, Mello e Souza T, Pereira P, et al. 2002. BDNF-triggered events in the rat hippocampus are required for both shortand long-term memory formation. Hippocampus 12: $551-260$

Alonso M, Vianna MR, Izquierdo I, Medina JH 2002. Signaling mechanisms mediating BDNF modulation of memory formation in vivo in the hippocampus. Cell Mol Neurobiol 22: 663-674.

Alonso M, Viola H, Izquierdo I, Medina JH. 2002. Aversive experiences are associated with a rapid and transient activation of ERKs in the rat hippocampus. Neurobiol Learn Mem 77: 119-124. 
Ardenghi P, Barros DM, Izquierdo LA, Bevilaqua L, Schröder N, Quevedo J, et al. 1997. Late and prolonged post-training memory modulation in entorhinal and parietal cortex by drugs acting on the $\mathrm{cAMP} /$ protein kinase $\mathrm{A}$ signalling pathway. Behav Pharmacol 8: 745-751.

Arriagada PV, Growdon JH, Hedley-Whyte ET, Hyman BT. 1992. Neurofibrillary tangles but not senile plaques parallel duration and severity of Alzheimer's disease. Neurology 42: 631-639.

Bahar, A, Anat, S, Dudai Y. 2003. The amygdalar circuit that acquires taste aversion memory differs from the circuit that extinguishes it. Eur J Neurosci 17: 1527-1530.

Barros DM, Izquierdo LA, Mello e Souza T, Ardenghi P, Pereira P, et al. 2000. Molecular signalling pathways in the cerebral cortex are required for retrieval of one-trial avoidance learning in rats. Behav Brain Res 114: 183-192.

Barros DM, Izquierdo LA, Medina JH, Izquierdo I. 2003. Pharmacological findings contribute to the understanding of the main physiological mechanisms of memory retrieval. Current Drug Targets: CNS \& Neurol Disorders 2: 81-94.

Barros DM, Mello e Souza T, De David T, Choi T, Aguzzoli A, et al. Simultaneous modulation of retrieval by dopaminergic $D_{1}, \beta$-noradrenergic, serotoninergic1A and cholinergic muscarinic receptors in cortical structures of the rat. Behav Brain Res 2001. 124: 1-7.

Barros DM, Mello E, Souza T, de Souza MM, Choi H, DeDavid E, et al. 2001. LY294002, an inhibitor of phosphoinositide 3-kinase given into rat hippocampus impairs acquisition, consolidation and retrieval of memory for one-trial inhibitory avoidance. Behav Pharmacol 12: 629-634.

Barros DM, Pereira P, Medina JH, I Izquierdo. 2002. Modulation of working memory and of long- but not short-term memory by cholinergic mechanisms in the basolateral amygdala. Behav Pharmacol 13: 163-167.

Basile AS. 1993. The role of benzodiazepine receptor ligands in the pathogenesis of hepatic encephalopathy. In: Izquierdo I, Medina $\mathrm{JH}$, eds, Natural Occurring Benzodiazepines: Structure, Distribution and Function. London, UK: Ellis Horwood; 89-114.

Beckett WS. 2002. Post-traumatic stress disorder. New Engl J Med 346: 1495-1498.

Beninger RJ, Dringenberg $\mathrm{HC}$, Boegman RJ, Jhamandas K. 2002. Cognitive effects of neurotoxic lesions of the nucleus basalis mangocellularis in rats: differential roles for corticopetal versus amygdalopetal projections. Neurotox Res 3: 7-21.

Berman DE, Dudai Y. 2001. Memory extinction, learning anew, and learning the new: dissociations in the molecular machinery of learning in cortex. Science 2001. 291: 417-2419.

Bernabeu R, Bevilaqua L, Ardenghi P, Bromberg E, Schmitz M, Bianchin M, et al. 1997. Involvement of hippocampal D1/D5 receptor-cAMP signaling pathways in late memory consolidation. Proc Natl Acad Sci USA 94: 7041-7046.

Bernabeu R, Schmitz P, Faillace MP, Izquierdo I, Medina JH. 1996. Hippocampal cGMP and cAMP are differentially involved in memory processing of an inhibitory avoidance learning. Neuroreport 7: 585-588.

Bernaerst P, Tirelli E. 2003. Facilitatory effect of the dopamine D4 receptor agonist PD168077 on memory consolidation of an inhibitory avoidance learned response in $\mathrm{C} 57 \mathrm{BL} / 6 \mathrm{~J}$ mice. Behav Brain Res 142: 41-52.

Bevilaqua L, Ardenghi P, Schröder N, Bromberg E, Schmitz E, Schaeffer E, et al. 1997. Drugs that influence the cyclic adenosine monophosphate/ protein kinase A signaling pathway alter memory consolidation when given late after training into rat hippocampus but not amygdala. Behav Pharmacol 8: 331-338.

Bevilaqua LRM, Cammarota M, Paratcha G, Levi de Stein M, Izquierdo I, Medina JH. 1999. Experience-dependent increase in cAMPresponsive element binding protein in synaptic and nonsynaptic mitochondria of the rat hippocampus. Eur J Neurosci 11, 3753-3756.

Bevilaqua LR, Kerr DS, Medina JH, Izquierdo I, Cammarota M. 2003. Inhibition of hippocampal Jun N-terminal kinase enhances short-term memory but blocks long-term memory formation and retrieval of an inhibitory avoidance task. Eur $\mathrm{J}$ Neurosci 17: 897-902.

Bianchin M, da Silva RC, Schmitz PK, Medina JH, Izquierdo I. 1994. Memory of inhibitory avoidance in the rat is regulated by glutamate metabotropic receptors in the hippocampus. Behav Pharmacol 5: 356-359.

Bloom J, Amador V, Bartolini F, DeMartino G, Pagano M. 2003. Proteasome-mediated degradation of p21 via $\mathrm{N}$-terminal ubiquitinylation. Cell 115: 71-82. 
Boccia MM, Acosta GB, Baratti CM. 2001. Memory improving actions of gabapentin in mice: possible involvement of central muscarinic cholinergic mechanism. Neurosci Lett 311: 153-156.

Boccia MM, Blake MG, Acosta GB, Baratti CM. 2003. Atropine, an anticholinergic drug, impairs memory retrieval of a high consolidated avoidance response in mice. Neurosci Lett 345: 97-100.

Bonini JS, Rodrigues L, Kerr DS, Bevilaqua LR, Cammarota M, Izquierdo, I. 2003. AMPA/kainate and group-I metabotropic receptor antagonists infused into different brain areas impair memory formation of inhibitory avoidance in rats. Behav Pharmacol 14: 161-166.

Bouton ME. 2002. Context, ambiguity, and unlearning: sources of relapse after behavioral extinction. Biol Psychiatry 52: 976-986.

Brioni JD. 1993. Role of GABA during the multiple consolidation of memory. Drug Develop Res 28: 3-27.

Bruins Slot LA, Chopin P, Colpaert FC. 2003. Tacrine-scopolamine interactions on statedependent retrieval. Psychopharmacology 166: 33-39.

Bruins Slot LA, Colpaert FC. 2003. A persistent opioid-addiction state of memory. Behav Pharmacol 14: 167-171.

Cahill L, Alkire MT. 2003. Epinephrine enhancement of human memory consolidation: interaction with arousal at encoding. Epinephrine enhancement of human memory consolidation: interaction with arousal at encoding. Neurobiol Learn Mem 19: 194-198.

Cammarota M, Bernabeu R, Izquierdo I, Medina JH. 1996. Reversible changes in hippocampal $3[\mathrm{H}]$ AMPA binding following inhibitory avoidance training in the rat. Neurobiol Learn Mem 66: 8588.

Cammarota M, Bernabeu R, Levi de Stein M, Izquierdo I, Medina JH. 1998. Learning-specific time-dependent increases in hippocampal $\mathrm{Ca}^{2+}$ / calmodulin-dependent protein kinase II activity and AMPA GluR1 subunit immunoreactivity. Eur J Neurosci 10: 2669-2676.

Cammarota M, Bevilaqua LR, Ardenghi P, Paratcha G, Levi de Stein M, et al. 2000. Learningassociated activation of nuclear MAPK, CREB and Elk-1, along with Fos production, in the rat hippocampus after a one-trial avoidance learning: abolition by NMDA receptor blockade. Brain Res Mol Brain Res 76: 36-46.

Cammarota M, Bevilaqua LRM, Kerr D, Medina JH, Izquierdo I. 2003. Inhibition of mRNA and protein synthesis in the $\mathrm{CA} 1$ region of the dorsal hippocampus blocks reinstallment of an extinguished conditioned fear response. J Neurosci 23: 737-741.

Cammarota M, Levi de Stein M, Paratcha G, Bevilaqua LRM, Izquierdo I, Medina JH. 2000. Rapid and transient learning-associated increase in NMDA NR1 subunit in rat hippocampus. Neurochem Res 2000. 25: 567-572.

Cangioli I, Baldi E, Mannaioni PF, Bucherelli C, Blandina P, Passani MB. 2002. Activation of histaminergic $\mathrm{H} 3$ receptors in the rat basolateral amygdala improves expression of fear memory and enhances acetylcholine release. Eur J Neurosci 16: 521-528.

Carlson G, Wang Y, Alger BE. 2002. Endocannabinoids facilitate the induction of LTP in the hippocampus. Nat Neurosci 5: 723-724.

Castellano C, Cestari V, Ciamei A. 2001. NMDA receptors and learning and memory processes. Curr Drug Targets 2: 273-283.

Cavallaro S, D'Agata V, Manickam P, Dufour F, Alkon DL. 2002. Memory-specific temporal profiles of gene expression in the hippocampus. Proc Natl Acad Sci USA 99: 16279-16284.

Chang Q, Gold PE. 2003. Switching memory systems during learning: changes in patterns of brain acetylcholine release in the hippocampus and striatum of rats. J Neurosci 23: 3001-3005.

Chen D, Wu CF, Shi B, Xu YM. 2002. Tamoxifen and toremifene cause impairment of learning and memory function in mice. Pharmacol Biochem Behav 71: 269-276.

Chen Z, Xu AJ, Li R, Wei EQ. 2002. Reversal of scopolamine-induced spatial memory deficits inm rats by TAK-147. Acta Pharmacologica Sinnica 23: 355-360.

Coitinho AS, Roesler R, Martins VR, Brentani RR, Izquierdo I. 2003. Cellular prion protein impairs behavior as a function of age. Neuroreport 14: 1375-1379.

Coitinho AS, Dietrich MO, Hoffmann A, Dall'Igna OP, Souza DO, Martins VR, et al. 2002. Decreased locomotion induced by MK-801, but not amphetamine and caffeine in mice lacking 
cellular prion protein $\left(\mathrm{PrP}^{\mathrm{c}}\right)$, but not amphetamine and caffeine. Mol Brain Res 107: 190-194.

Colley PA, Routtenberg A. 1993. Long-term potentiation as synaptic dialogue. Brain Res Rev 18: 115-122.

Colpaert FC, Koek W, Bruins Slot LA. 2001. Evidence that mnesic states govern normal and disordered memory. Behav Pharmacol 12: 575-589.

Conner JM, Culberson A, Packowski C, Chiba AA, Tuszynski MH. 2003. Lesions of the basal forebrain cholinergic system impair task acquisition and abolish cortical plasticity associated with motor learning. Neuron 38: 819-829.

Cordero M., Kruyt ND, Merino JJ, Sandi C. 2002. Glucocorticoid involvement in memory formation in a rat model for traumatic memory. Stress 5: 7379.

Corcoran KA, Maren S. 2001. Hippocampal inactivation disrupts contextual retrieval of fear memory after extinction. J Neurosci 21: 1720-1726.

Costanzi M, Battaglia M, Populin R, Cestari V, Castellano C. 2003. Anandamide and memory in CD1 mice: effects of immobilization stress and of prior experience. Neurobiol Learn Mem 79: 204211.

Da S, Takahashi RN. 2002. SR141716A prevents delta 9-tetrahydrocannabinol-induced spatial learning deficit in a Morris-type water maze in mice. Prog Neuropsychopharmacol Biol Psychiatry 26: 321325.

Darnaudery M, Pallares M, Piazza PV, LeMoal M, Mayo W. 2002. The neurosteroid pregnenolone sulfate infused into the medial septum nucleus increases hippocampal acetylcholine and spatial memory in rats. Brain Res 95: 237-242.

Davis M, Walker DL, Myers KM. 2003. Role of the amygdala in fear extinction measured with potentiated startle. Ann NY Acad Sci 985: 218-232.

Day M, Langston R, Morris RG. 2001. Glutamatereceptor-mediated encoding and retrieval of paired-associate learning. Nature 424: 205-209.

Day M, Morris RG. 2001. Memory consolidation and NMDA receptors: discrepancy between genetic and pharmacologic approaches. Science 293: 755.

De Almeida MAMR, Izquierdo I. 1988. Intracerebroventricular histamine, but not $48 / 80$, causes posttraining memory facilitation in the rat. Arch Int Pharmacodyn Ther 291: 202-208.

De Almeida MAMR, Izquierdo I. 1986. Memory facilitation by post-training histamine administration.
Arch Int Pharmacodyn Ther 283: 193-198.

Debiec J, LeDoux JE, Nader K. 2002. Cellular and systems reconsolidation in the hippocampus. Neuron 36: 527-538.

De Blas A, Sangameswaran L. 1986. Demonstration and purification of an endogenous benzodiazepine from the mammalian brain with a monoclonal antibody to benzodiazepines. Life Sciences 39: 1927-1936.

De Leonibus E, Lafenetre P, Oliverio A, Mele A. 2003. Pharmacological evidence for the role of dorsal striatum in spatial memory consolidation in mice. Behav Neurosci 117: 685-694.

De-Mello N, Carobrez AP. 2002. Elevated T-maze as an animal model of memory: effects of scopolamine. Behav Pharmacol 13: 139-148.

De-Paris F, Busnello JV, Vianna MR, Salgueiro JB, Quevedo J, Izquierdo I, et al. 2000. The anticonvulsant compound gabapentin possesses anxiolytic but not amnesic effects in rats. Behav Pharmacol 11: 169-173.

De-Paris F, Sant'Anna MK, Vianna MR, Barichello T, Busnello JV, Kapczinski F, et al. 2003. Effects of gabapentin on anxiety induced by simulated public speaking. J Psychopharmacol 17: 184-188.

De Quervain DJ, Henke, Aerni A, Treyer V, McGaugh JL, Berthold T, et al. 2003. Glucocorticoid-induced impairment of declarative memory retrieval is associated with reduced blood flow in the medial temporal lobe. Eur J Neurosci 17: 1296-1302.

Diez-Ariza M, Redondo C, García-Alloza M, Lasheras B, Del Río J, Ramírez MJ. 2003. Flumazenil and tacrine increase the effectiveness of ondansetron on scopolamine-induced impairment of spatial learning in rats. Psychopharmacology 169: 35-41.

Disterhoft JF, Oh MM. 2003. Modulation of cholinergic transmission enhances excitability of hippocampal pyramidal neurons and ameliorates learning impairments in aging animals. Neurobiol Learn Mem 80: 223-233.

Edwards TM, Rickard NS. 2002. Inhibition of monoADP-ribosylation prevents long-term memory consolidation of a single-trial passive avoidance task in the day-old chick. Neurobiol Learn Mem 78: 192-198.

Edwards TM, Rickard NS, Ng KT. 2002. Inhibition of guanylate cyclase and protein kinase $\mathrm{G}$ impairs retention for the passive avoidance task in the dayold chick. Neurobiol Learn Mem 77: 313-326. 
Eichenbaum H, Schoenbaum G, Young B, Bunsey M. 1996. Functional organization of the hippocampal memory system. Proc Natl Acad Sci USA 93: 13500-13507.

Eisenberg M, Kobilo T, Berman DE, Dudai Y. 2003. Stability of retrieved memory: inverse correlation with trace dominance. Science 301: 1102-1104.

El Fakhri G, Kijewski MF, Johnston KA, Syrkin G, Killany RJ, Becker JA, et al. 2003. MRI-guided SPECT perfusion measures and volumetric MRI in prodromal Alzheimer disease. Arch Neurol 60: 1066-1072.

Epstein HT, Child FM, Kuzirian AM, Alkon DL. 2003. Time windows for effects of protein synthesis inhibitors on Pavlovian conditioning in Hermissenda: behavioral aspects. Neurobiol Learn Mem 79: 127-131.

Ezzedine Y, Glanzman DL. 2003. Prolonged habituation of the gill-withdrawal reflex in Aplysia depends on protein synthesis, protein phosphatase activity, and postsynaptic glutamate receptors. J Neurosci 23: 9585-9594.

Falls, WA, Miserendino MJ, Davis M. Extinction of fear-potentiated startle: blockade by infusion of an NMDA antagonist into the amygdala. J Neurosci 1992. 12: 854-863.

Fedosiewicz-Wasuluk M, Holy ZZ, Wisniewski K. 2002. L-AP4, a potent agonist of group III metabotropic glutamate receptor, decreases central action of angiotensin II. Pol J Pharmacol 54: 415422.

Ferreira AR, Furstenau L, Blanco C, Kornisiuk E, Sánchez G, Daroit D, et al. 2003. Role of hippocampal M1 and M4 muscarinic receptor subtypes in memory consolidation in the rat. Pharmacol Biochem Behav 74: 411-415.

Fischer A, Sananbenesi F, Shrick C, Spiess J, Radulovic J. 2003. Regulation of contextual fear conditioning by baseline and inducible septohippocampal cyclin-dependent kinase 5 . Neuropharmacology 44: 1089-1099.

Francis PT. Glutamatergic systems in Alzheimer's disease. International Journal of Geriatric Psychiatry 2003. 18: S15-S21.

Frye CA, Lacey EH. 2001. Post-training androgens' enhancement of cognitive performance is temporally distinct from androgens' increases in affective behavior. Cogn Affect Behav Neurosci 1: 172-182.

Gais S, Sommer M, Fischer S, Perras B and Born J.
2002. Post-trial administration of vasopressin in humans does not enhance memory formation. Peptides 23: 581-583.

Geinisman Y, Berry RW, Disterhoft JF, Power JM, van der Zee E. 2001. Associative learning elicits the formation of multiple-synaptic boutons. J Neurosci 21: 5569-5573.

Giacobini E. 2003. Cholinergic function and Alzheimer's disease. Int J Geriatr Psychiatry 18: S1-S5.

Gibbs ME, Summers J. 2001a. Enhancement of memory consolidation in chicks by beta(3)-adrenoceptor agonists. Eur J Pharmacol 413: 235-240.

Gibbs ME, Summers J. 2001b. Stimulation of alpha1adrenoceptors inhibits memory consolidation in the chick. Eur J Neurosci 14: 1369-1376.

Gibbs ME, Summers J. 2002. Effects of glucose and 2-deoxyglucose on memory formation in the chick: interaction with beta(3)-adrenoceptor agonists. Neuroscience 114: 69-79.

Gibbs ME, Summers J. 2003. Alpha 2-adrenoceptors in the basal ganglia have a role in memory consolidation and reinforcement. Neuropharmacology 45: 255-367.

Girdler NM, Lyne JP, Wallace R, Neave N, Scholey A, Wesnes KA, et al. 2002. A randomised, controlled trial of cognitive and psychomotor from midazolam sedation following reversal with oral flumazenil. Anaesthesia 57: 868-876.

Gold PE. 2003. Acetylcholine modulation of neural systems involved in learning and memory. Neurobiol Learn Mem 80: 194-210.

Gold PE. 1986. Glucose modulation of memory storage processing. Behav Neural Biol 45: $342-$ 349.

Gold PE, McGaugh JL. 1975. A single trace, dual process view of memory storage processes. In Deutsch D, Deutsch JA. eds, Short-Term Memory. New York, NY, USA: Academic Press; 355-378.

Goldman-Rakic P. 1996. Regional and cellular fractionation of working memory. Proc Natl Acad Sci USA 93: 13473-13480.

Grevet EH, Tietzmann MRM, Shansis FM, Hastenpflugl C, Santana LC, Forster L, et al. 2002. Behavioural effect of acute phenylalanine and tyrosine depletion in healthy male volunteers. J Psychopharmacol 16: 51-55.

Gutiérrez R, Tellez LA, Bermúdez-Rattoni F. 2003. Blockade of cortical muscarinic but not NMDA receptors prevents a novel taste from becoming 
familiar. Eur J Neurosci 17: 1556-1562.

Hale MW, Crowe SF. 2002. The effects of selective dopamine agonists on a passive avoidance learning task in the day-old chick. Pharmacology 13: 295-301.

Hall J, Thomas KL, Everitt BJ. 2000. Rapid and selective induction of BDNF expression in the hippocampus during contextual learning. Nat Neurosci 3: 533-535.

Hardy J. 2003. The relationship between amyloid and tau. J Mol Neurosci 20: 203-206.

Harris JA, Westbrook RF. 1999. The benzodiazepine midazolam does not impair Pavlovian fear conditioning but regulates when and where fear is expressed. J Exp Psychol Anim Behav Process 25: 236-246.

Hebert AE, Dash PK. 2002. Extracellular signalregulated kinase activity in the entorhinal cortex is necessary for long-term spatial memory. Learn Mem 9: 156-166.

Hensbroek RA, Kamal A, Baars AM, Verhage M, Spruijt BM. 2003. Spatial, contextual and working memory are not affected by the absence of mossy fiber long-term potentiation and depression. Behav Brain Res 138: 215-223.

Hernández PJ, Sadeghian K, Kelley AE. 2002. Early consolidation of instrumental learning requires protein synthesis in the nucleus accumbens. Nat Neurosci 5: 1327-1331.

Hirsh R. 1974. The hippocampus and contextual retrieval of information from memory: a theory. Behav Biol 12: 421-444.

Hlinak Z, Krejci I. 2002. Oxiracetam prevents the scopolamine but not the diazepam induced memory deficits in mice. Behav Brain Res 133: 395-399.

Hock C, Konietzko U, Streffer JR, Tracy J, Signorell A, Müller-Tillmans B, et al. 2003. Antibodies against $\beta$-amyloid slow cognitive decline in Alzheimer's disease. Neuron 2003. 38: 547-554.

Hope AD, de Silva R, Fischer DF, Hol EM, van Leeuwen FW, Lees AJ. 2002. Alzheimer's associated variant ubiquitin causes inhibition of the $26 \mathrm{~S}$ proteasome and chaperone expression. $\mathrm{J}$ Neurochem 86: 394-404.

Hsu FC, Garside MJ, Massey AE, McAllisterWiliams RH. 2003. Effects of a single dose of cortisol on the neural correlates of episodic memory and error processing in healthy volunteers. Psychopharmacology 167: 431-442.
Hyman BT, van Hoesen GW, Damasio A. 1990. Memory-related neural systems in Alzheimer's disease: an anatomic study. Neurology 40: 17211730.

Igaz LM, Bekinschtein P, Vianna MRM, Izquierdo I, Medina JH. 2004. Gene expression during memory formation. Neurotox Res 6: 189-204.

Igaz LM, Vianna MR, Medina JH, Izquierdo I. 2002. Two time periods of hippocampal RNA synthesis are required for memory consolidation of fearmotivated learning. J Neurosci 22: 6781-6789.

Izquierdo I. 1989. Different forms of post-training memory processing. Behav Neural Biol 51: 171202.

Izquierdo I. 1984. Endogenous state dependency: Memory depends on the relation between the neurohumoral and hormonal states present after training and at the time of testing. In: Lynch G, McGaugh JL, Weinberger NM, eds, Neurobiology of Learning and Memory, New York, NY, USA: Guilford Press; 333-350.

Izquierdo I. 1979. Effect of naloxone and morphine on various forms of memory in the rat: Possible role of endogenous opiate mechanisms in memory consolidation. Psychopharmacology 1979: 66, 199-203.

Izquierdo I. 1991. Opioids and memory. In: Stone TW, ed, Aspects of Synaptic Transmission, London, UK: Taylor \& Francis; 162-178.

Izquierdo I, Da Cunha C, Rosat R, Jerusalinsky D, Ferreira MBC, Medina JH. 1992. Neurotransmitter receptors involved in post-training memory processing by the amygdala, medial septum and hippocampus of the rat. Behav Neural Biol 58: 16-26.

Izquierdo I, Fin C, Schmitz PK, Da Silva RC, Jerusalinsky D, Quillfeldt JA, et al. 1995. Memory enhancement by intrahippocampal, intra-amygdala, or intra-entorhinal infusion of platelet-activating factor. Proc Natl Acad Sci USA 92: 5047-5051.

Izquierdo I, McGaugh JL. 2000. Behavior pharmacology and its contribution to the molecular basis of memory consolidation. Behav Pharmacol 11: 517-534.

Izquierdo I, Medina JH. 1991. GABA receptor modulation of memory: the role of endogenous benzodiazepines. Trends Pharmacol Sci 1991. 12: 260-265.

Izquierdo I, Medina JH. 1997. Memory formation: the sequence of biochemical events in the 
hippocampus and its connection to activity in other brain structures. Neurobiol Learn Mem 68: 285-316.

Izquierdo I, Medina JH, Vianna MR, Izquierdo LA, DM Barros. 1999. Separate mechanisms for shortand long-term memory. Behav Brain Res 103: 1-11.

Izquierdo, JA, Insúa JA, Biscardi AM, Izquierdo I. 1959. Some observations on the responses to stimulation of the afferent vagus nerve. Med Exp 1: 325-332.

Izquierdo LA, Barros DM, Medina JH, Izquierdo I. 2002. Stress hormones enhance retrieval of fear conditioning acquired one day or many months before. Behav Pharmacol 13: 203-214.

Izquierdo LA, Barros DM, Vianna MR, Coitinho A, De David e Silva T, Choi T, et al. 2002. Molecular pharmacological dissection of shortand long-term memory . Cell Mol Neurobiol 22: 269-287.

Izquierdo LA, Barros DM, Medina JH, Izquierdo I. 2003. Exposure to novelty enhances retrieval of very remote memory in rats. Neurobiol Learn Mem 79: $51-58$.

Izquierdo LA, Barros DM, Medina JH, Izquierdo I. 2000. Novelty enhances retrieval of one-trial avoidance learning in rats 1 or 31 days after training unless the hippocampus is inactivated by different receptor antagonists and enzyme inhibitors. Behav Brain Res 117: 215-220.

Janus C. 2003. Vaccines for Alzheimer's disease: how close are we? CNS Drugs 17: 457-474.

Jezek K, Wesierska M, Fenton AA. 2002. Hippocampus-dependent retrieval and hippocampusindependent extinction of place avoidance navigation, and stress-induced out-of-context activation of a memory revealed by reversible lesion experiments in rats. Physiol Res 51 Suppl 1: S35-S47.

Jerusalinsky D, Ferreira MBC, Walz R, Da Silva RC, Bianchin M, Ruschel AC, et al. 1992. Amnesia by post-training infusion of glutamate receptor antagonists into the amygdala, hippocampus and entorhinal cortex. Behav Neural Biol 58: 76-80.

Johnston AN, Migues PV. 2001. Task- and timedependent memory enhancement by dehydroepiandrosterone in day-old chicks. Neural Plast 8: 255-270.

Karas GB, Buron EJ, Rombouts SA, van Shijndel RA, O'Brien JT, Scheltens P, et al. 2003. A comprehensive study of gray matter loss in patients with Alzheimer's disease using optimized voxel-based morphometry. Neuroimage 18: 895907.

Katona I, Rancz EA, Acsady L, Ledent C, Mackie,K, Hajos N, et al. 2001. Distribution of CB1 cannabinoid receptors in the amygdala and their role in the control of GABAergic transmission. J Neurosci 21: 9506-9518.

Kelly A, Laroche S, Davis S. 2003. Activation of mitogen-activated protein kinase/extracellular signal-regulated kinase in hippocampal circuitry is required for consolidation and reconsolidation of recognition memory. J Neurosci 23: 5354-5360.

Kemppainen N, Laine M, Laakso MP, Kaasinen V, Nagren K, Vahlberg T, et al. 2003. Hippocampal dopamine D2 receptors correlate with memory functions in Alzheimer's disease. Eur J Neurosci 18: 149-154.

Khavandgar S, Homayoun H, Zarrindast MR. 2003. The effect of L-NAME and L-arginine on impairment of memory formation and statedependent learning induced by morphine in mice. Psychopharmacology 167: 291-296.

Kilgard M. 2003. Cholinergic modulation of skill learning and plasticity. Neuron 38: 678-60.

Koh MT, Bernstein IL. 2003. Inhibition of protein kinase A activity during conditioned taste aversion retrieval: interference with extinction or reconsolidation of a memory? Neuroreport 14: 405407.

Koh MT, Thiele TE, Bernstein IL. 2002. Inhibition of protein kinase A activity interferes with longterm, but not short-term, memory of conditioned taste aversion. Behav Neurosci 116: 1070-1074.

Konishi Y, Beach T, Sue LI, Hampel H, Lindholm K, Shen Y. 2003. The temporal localization of frameshift ubiquitin-B and amyloid precursor protein, and complement proteins in the brain of nondemented control patients with increasing Alzheimer's disease pathology. Neurosci Lett 348: 46-50.

Kraus M, Schicknick H, Wetzel W, Ohl F, Staak S, Tischmeyer W. 2002. Memory consolidation for the discrimination of frequency-modulated tones in mongolian gerbils is sensitive to protein synthesis inhibitors applied to the auditory cortex. Learn Mem 9: 293-303.

LaLumiere RT, Buen TV, McGaugh JL. 2003. Posttraining intra-basolateral amygdala infusions of norepinephrine enhance consolidation of memory 
for contextual fear conditioning. J Neurosci 23: 6754-6758.

Lamirault L, Guillou C, Thal C, Simon H. 2003. Combined treatment with galanthaminium bromide, a new cholinesterase inhibitor, and RS67333, a partial agonist of 5-HT4 receptors, enhances place and objet recognition in young adult and old rats. Prog Neuropharmacol Biol Psychiatry 27: 185-195.

Lattal KM, Abel T. 2004. Behavioral impairments caused by injection of the protein synthesis inhibitor anisomyxin after contextual fear retrieval reverses with time. Proc Natl Acad Sci USA 101: 2667-2672.

Lattal KM, Abel T. 2001. Different requirements for protein syntheis in acquisition and extinction of spatial preferences and context-evoked fear. J Neurosci 21: 5773-5780.

Lee AL, Ogle WO, Sapolsky RM. 2002. Stress and depression: possible links to neuron death in the hippocampus. Bipolar Disord 4: 117-128.

Lin $\mathrm{CH}$, Yeh SH, Leu TH, Chang WC, Gean PW. 2003. Identification of calcineurin as a key signal in the extinction of fear memory. $\mathrm{J}$ Neurosci 23: 1574-1579.

Lin $\mathrm{CH}$, Yeh SH, Lin C-H, Lu KT, Leu TH, Chang WC, et al. 2001. A role for the PI-3 kinase signaling pathway in fear conditioning and synaptic plasticity in the amygdala. Neuron 31 : 841-851.

Locatelli F, Maldonado H, Romano A. 2002. Two critical periods for cAMP-dependent protein kinase activity during long-term memory consolidation in the crab Chasmagnathus. Neurobiol Learn Mem 77: 234-249.

López-Salón M, Alonso M, Vianna MR, Viola $\mathrm{H}$, Mello e Souza T, Izquierdo I, et al. 2001. The ubiquitin-proteasome cascade is required for mammalian long-term memory formation. Eur $\mathbf{J}$ Neurosci 14: 1820-1826.

López-Salón M, Morelli L, Castano EM, Soto EF, Pasquini JM. 2000. Defective ubiquitination of cerebral proteins in Alzheimer's disease. J Neurosci Res 62: 302-310.

López-Salón $M$, Pasquini L, Besio Moreno $M$, Pasquini JM, Soto E. 2003. Relationship between beta-amyloid degradation and the $26 \mathrm{~S}$ proteasome in neural cells. Exp Neurol 180: 131-143.

Lu KT, Walker DL, Davis M. 2001. Mitogenactivated protein kinase cascade in the basolateral nucleus of amygdala is involved in extinction of fear-potentiated startle. J Neurosci 21: RC162.

Luine VN, Jacome JF, Maclusky NJ. 2003. Rapid enhancement of visual and place memory by estrogens in rats. Endocrinology 144: 2836-2844.

McAliister-Williams RH, Rugg MD. 2002. Effects of repeated cortisol administration on brain potential correlates of episodic memory retrieval. Psychopharmacology 160: 74-83.

McAllister-Williams RH, Massey AE, Rugg MD. 2002. Effects of tryptophan depletion on brain potential correlates of episodic memory retrieval. Psychopharmacology 160: 434-442.

McGaugh JL, Castellano C, Brioni J. 1990. Picrotoxin enhances latent extinction of conditioned fear. Behav Neurosci 104: 264-267.

McGaugh JL, Izquierdo I. 2000. The contribution of pharmacology to research on the mechanism of memory formation, Trends Pharmacol Sci 21: 208-210.

McIntyre CK, Marriott LK, Gold PE. 2003. Cooperation between memory systems: acetylcholine release in the amygdala correlates positively with performance on a hippocampus-dependent task. Behav Neurosci 117: 320-326.

McIntyre CK, Pal SN, Marriott LK, Gold PE. 2002. Competition between memory systems: acetylcholine release in the hippocampus correlates negatively with good performance on an amygdaladependent task. J Neurosci 22: 1171-1176.

McIntyre CK, Power AE, Roozendaal B, McGaugh JL. 2003. Role of the basolateral amygdala in memory consolidation. Ann NY Acad Sci 985: 273-293.

McLin DE $3^{\text {rd }}$, Miasnikov AA, Weinberger NM. 2003. CS-specific gamma, theta, and alpha EEG activity detected in stimulus generalization following induction of behavioral memory by stimulation of the nucleus basalis. Neurobiol Learn Mem 79: 152-176.

McNay EC, Gold PE. 2001. Age-related differences in hippocampal extracellular fluid glucose concentration during behavioral testing and following systemic glucose administration. J Gerontol A: Biol Sci Med Sci 56: B66-B71.

McNay EC, McCarty RC, Gold PE. 2001. Fluctuations in brain glucose concentration during behavioral testing: dissociations between brain areas and between brain and blood. Neurobiol Learn Mem 75: 325-327. 
Marsicano G, Goodenough S, Monory K, Hermann H, Eder M, Cannich A, et al. 2003. CB1 cannabinoid receptors and on-demand defense against excitotoxicity. Science 302: 84-88.

Marsicano G, Wojtak CT, Azad SC, Bisogno T, Rammes G, Cascio MG, et al. 2002. The endogenous cannabinoid system controls extinction of aversive memories. Nature 418: 530-534.

Martin JH. 1991. Autoradiographic matching of the extent of reversible inactivation produced by microinjection of lidocaine and muscimol in the rat. Neurosci Lett 127: 160-164.

Martins VR, Linden R, Prado MAM, Walz R, Sakamoto AC, Izquierdo I, et al. 2002. Cellular prion protein: on the road for functions. FEBS Lett 512: 25-28.

Matthies H. 1989. In search of the cellular mechanisms of memory. Prog Neurobiol 32: 277-349.

Medina JH, Izquierdo I. 1995. Retrograde messengers, long-term potentiation and memory processes. Brain Res Rev 21: 185-194.

Meneses A. 2001. Could the 5HT1B receptor inverse agonism affect learning consolidation? Neurosci Biobehav Rev 25: 193-201.

Meneses A. 2002. Involvement of $5 \mathrm{HT}(2 \mathrm{~A} / 2 \mathrm{~B} / 2 \mathrm{C})$ receptors on memory formation: simple agonism, antagonism or inverse agonism? Cell Mol Neurobiol 22: 675-688.

Metzger MM, Flint RW Jr. 2003. Glucose enhancement of face recognition is unaffected by alterations of face features. Neurobiol Learn Mem 80: 172-175.

Milekic M, Alberini CM. 2002. Temporally graded requirement for protein synthesis following memory reactivation. Neuron 38: 521-525.

Miranda ML, Ferreira G, Ramírez-Lugo L, BermúdezRattoni F. 2002. Glutamatergic activity in the amygdala signals visceral input during taste memory formation. Proc Natl Acad Sci USA 99: 11417-11422.

Miserendino MJ, Sananes CB, Melia KR, Davis, M. 1990. Blocking of acquisition but not expression of conditioned fear-potentiated startle by NMDA antagonists in the amygdala. Nature 345: 716-718.

Mishima K, Egashira N, Hirosawa N, Fujii M, Matsumoto Y, Iwasaki K, et al. 2001. Characteristics of learning and memory impairment induced by delta9-tetrahydrocannabinol in rats. Jpn J Pharmacol 87: 297-308.

Morris RGM, Anderson E, Lynch GS, Baudry M.
1986. Selective impairment of learning and blockade of long-term potentiation by an $N$ methyl-D-aspartate receptor antagonist, AP5. Nature 297: 681-683.

Myers KM, Davis M. 2002. Behavioral and neural analysis of extinction. Neuron 567-584.

Nader K. Memory traces unbound. 2002. Trends Neurosci 26: 65-72.

Nader K, Schafe GE, Le Doux JE. 2000. Fear memories require protein synthesis in the amygdala for reconsolidation. Nature 406: 722-726.

Nakazawa K, Sun LD, Quirk MC, Rondi-Reig L, Wilson MA, Tonegawa S. 2003. Hippocampal CA3 NMDA receptors are crucial for memory acquisition on one-time experience. Neuron 147148.

Orsetti M, Ferretii C, Gamalero R, Ghi P. 2002. Histamine H3-receptor blockade in the rat nucleus basalis magnocellularis improves place recognition memory. Psychopharmacology 159: 133-137.

Orsetti M, Ghi P, Di Caro G. 2001. Histamine H(3)receptor antagonism improves memory retention and reverses the cognitive deficit induced by scopolamine in a two-place recognition task. Behav Brain Res 124: 235-242.

Paban V, Soumireu-Mourat B, Alescio-Lautier B. 2003. Behavioral effects of arginine-8-vasopressoin in the Hebb-Williams maze. Behav Brain Res 141: 1-9.

Packard MG, Vecchioli SF, Schroeder JP, Gasbarri A. 2001. Task-dependent role for dorsal striatum metabotropic glutamate receptors in memory. Learn Mem 8: 96-103.

Paquette V, Levesque J, Mansour B, Leroux JM, Beaudoin G, Borgouin P, et al. 2003. Change the mind and you change the brain: effects of cognitive-behavioral therapy on the neural correlates of spider phobia. Neuroimage 18: 401409.

Pakaski M, Kasa P. 2003. Role of acetylcholinesterase inhibitora in the metabolism of amyloid precursr protein. Curr Drug Targets CNS Neurol Disord 2: 163-171.

Paratcha G, Furman M, Bevilaqua L, Cammarota M, Vianna M, de Stein ML, et al. 2000. Involvement of hippocampal PKC $\beta$ I isoform in the early phase of memory formation of an inhibitory avoidance learning. Brain Res 855: 199-205.

Paratcha G, Ledda F, Ibanez CF. 2003. The neural cell adhesion molecule NCAM is an alternative 
signaling receptor for GDNF family ligands. Cell 113: 867-879.

Passani MB, Cangioli I, Baldi E, Bucherelli C, Mannaioni PF, Blandina P. 2001. Histamine H3 receptor-mediated impairment of contextual fear conditioning and in vivo inhibition of cholinergic transmission in the rat basolateral amygdala. Eur $\mathrm{J}$ Neurosci 14: 1522-1532.

Pereira GS, Mello e Souza T, Battastini AMO, Izquierdo I, Sarkis JJF, Bonan CD. 2002. Effects of inhibitory avoidance training and/or isolated foot-shock on ectonucleotidase activities in synaptosomes from the anterior and posterior cingulate cortex and the medial precentral area of adult rats. Behav Brain Res 128: 121-127

Pereira GS, Walz R, Bonan CD, Battastini AMO, Izquierdo I, Martins VR, et al. 2001. Changes in cortical and hippocampal ectonucleotidase activities in mice lacking cellular prion protein. Neurosci Lett 301: 72-74.

Perry EK, Kilford L, Lees AJ, Burn DJ, Perry RH. Increased Alzheimer pathology in Parkinson's disease related to antimuscarinic drugs. Ann Neurol 2003. 54: 235-238.

Picada JN, Schröder N, Izquierdo I, Henriques JAP, Roesler R. 2002. Differential neurobehavioral deficits induced by apomorphine and its oxidation product, 8-oxo-apomorphine-semiquinone, in rats. Eur J Pharmacol 443: 105-111.

Pitsikas N, Rigamonti AE, Cella SG, Muller EE. 2002. Effect of the nitric oxide donor molsidomine on different memory components as assessed in the object-recognition task in rats. Psychopharmacology 162: 239-245.

Porciuncula L, Schmidt A, Coitinho AS, Vinadé E, Izquierdo I, Rocha J, et al. 2002. Intrahippocampal infusion of ebselen impairs retention of an inhibitory avoidance task in rats. Eur $\mathbf{J}$ Pharmacology 451: 165-168.

Porter AC, Sauer JM, Knierman MD, Becker GW, Berna MJ, Bao J, et al. 2002. Characterization of a novel endocannabinoid, virodhamine, with antagonistic activity at the $\mathrm{CB} 1$ receptor. J Pharmacol Exp Ther 301: 1020-1024.

Power AE, Vazdarjanova A, McGaugh JL. 2003. Muscarinic cholinergic influences in memory consolidation. Neurobiol Learn Mem 80: 178-193.

Prado-Alcalá. 1995. Serial and parallel processing during memory consolidation. In: McGaugh JL, Bermudez-Rattoni FE, Prado-Alcalá RA, eds,
Plasticity in the Central Nervous System. Mahwah, New Jersey, USA: Lawrence Erlbaum; 171-184.

Prado-Alcalá RA, Ruiloba MI, Rubio L, SolanaFigueroa R, Medina C, Salado-Castillo R, et al. 2003. Regional infusions of serotonin into the striatum and memory consolidation. Synapse 47: 169-175.

Quevedo J, De-Paris F, Vianna MR, Barichello T, Roesler R, Kapczinski F. 2002. Interaction between midazolam-induced anterograde amnesia and memory enhancement by treatments given immediately after training on an inhibitory avoidance task in rats. Behav Pharmacol 13: 319322.

Qiu J, Bosch MA, Tobias SC. Grandy DK, Scanlan TS, Ronnekiev OK, et al. 2003. Rapid signaling of estrogen in hippocamthalamus neurons involves a novel G-protein-coupled estrogen receptor that activates protein kinase C. J Neurosci 2003. 95299540.

Ressler KJ, Paschall G, Zhou XL, Davis M. 2002. Regulation of synaptic plasticity genes during consolidation of fear conditioning. J Neurosci 22: 7892-7902.

Riedel G. 1996. Function of metabotropic glutamate receptors in learning and memory. Trends Neurosci 19: 219-224.

Riedel G, Platt B, eds. 2004 (in press). Memories are Made of These: From Messengers to Molecules. , London, UK: Landes Bioscience/Eureka Pubmed. http://www.eurekah.com/isbn.php?isbn=0-306$47862-5$ \&bookid $=97 \&$ catid $=48$

Riedel G, Platt B, Micheau J. 2003. Glutamate receptor function in learning and memory. Behav Brain Res 140: 1-47.

Rodrigues SM, Bauer EP, Farb CR, Schafé GE, LeDoux JE. 2002. The group I metabotropic glutamate receptor $\mathrm{mGluR}_{5}$ is required for fear memory formation and long-term potentiation in the lateral amygdala. J Neurosci 22: 5219-5229.

Rodrigues SM, Schafé GE, LeDoux JE. 2001. Intraamygdala blockade of the NR2B subunit of the NMDA receptor disrupts the acquisition but not the expression of fear conditioning. $\mathrm{J}$ Neurosci 21: 6889-6896.

Roesler R, Meller A, Kopshina MI, Souiza DO, Henriques JA, Schwartsmann. 2003. Intrahippocampal infusion of the bombesin/gastrin-releasing peptide antagonist RC3095 impairs inhibitory avoidance retention. Peptides 24: 1069-1074. 
Roesler R, Schröder N, Vianna MR, Quevedo J, Bromberg E, Kapczinski F, et al. 2003. Differential involvement of hippocampal and NMDA receptors in contextual and aversive aspects of inhibitory avoidance memory in rats. Brain Res 975: 207-213.

Rogers JL, Kesner RP. 2003. Cholinergic modulation of the hippocampus during encoding and retrieval. Neurobiol Learn Mem 80: 332-342.

Roldán G, Cobos-Zapiain G, Quirarte GL, PradoAlcalá RS. 2001. Dose- and time-dependent scopolamine-induced recovery of an inhibitory avoidance response after its extinction in rats. Behav Brain Res 121: 173-179.

Roozendaal B. 2002. Stress and memory: opposing effects of glucocorticoids on memory consolidation and memory retrieval. Neurobiol Learn Mem 78: 578-595.

Roozendaal B, Griffith QK, Buranday J, de Quervain DJ, McGaugh JL. 2003. The hippocampus mediates glucocorticoid-induced impairment of spatial memory retrieval: dependence on the basolateral amygdala. Proc Natl Acad Sci USA 100: 1328-1333.

Roozendaal B, Phillips RG, Power AE, Brooke SM, Sapolsky RM, McGaugh JL. 2001. Memory retrieval impairment induced by hippocampal CA3 lesions is blocked by adrenocortical suppression. Nat Neurosci 4: 1169-1171.

Roozendaal B, Quirarte GL, McGaugh JL. 2002. Glucocorticoids interact with the basolateral amygdala beta-adrenoceptor-cAMP/cAMP/PKA system in influencing memory consolidation. Eur J Neurosci 15: 553-560.

Rosatto J, Bonini JS, Coitinho AS, Vianna MR, Medina JH, Cammarota M, et al. 2004. Retrograde amnesia induced by drugs acting on different molecular systems depends on how long after training these drugs are infused in selected brain areas. Behav Neurosci 118: 563-568.

Rose JK, Kaun KR, Chen SH, Rankin CH. 2003. GLR-1, a non-NMDA glutamate receptor homolog, is critical for long-term memory in Caenorhabditis elegans. J Neurosci 23: 9595-9599.

Rose SPR. 1995. Time-dependent biochemical and cellular processes in memory formation. In: McGaugh JL, Bermudez-Rattoni FE, Prado-Alcalá RA. Plasticity in the Central Nervous System. Mahwah, New Jersey, USA: Lawrence Erlbaum; 171-184.

Rothbaum BO, Schwartz AC. 2002. Exposure therapy for posttraumatic stress disorder. Am J Psychother 56: 59-75.

Routtenberg A. 2000. It's about time. In: Gold PE, Greenough WT, eds, Memory Consolidation. Washington, DC, USA: American Psychological Association; 17-34.

Routtenberg A. 1995. Knockout mouse fault lines. Nature 374: 314-315.

Roy M, Sapolsky RM. 2003. The exacerbation of hippocampal excitotoxicity by glucocorticoids is not mediated by apoptosis. Neuroendocrinology 77: 24--31.

Sachetti B, Lorenzini CA, Baldi E, Tassoni G, Bucherelli C. 1999. Auditory thalamus, dorsal hippocampus, basolateral amygdala, and perirhinal cortex role in the consolidation of conditioned freezing to context and to acoustic conditioned stimulus in the rat. J Neurosci 19: 9570-9578.

Sanders MJ, Fanselow MS. 2003. Pre-training prevents context fear conditioning deficits produced by hippocampal NMDA receptor blockade. Neurobiol Learn Mem 80: 123-129.

Sapolsky RM. 2001. Atrophy of the hippocampus in posttraumatic stress disorder: how and when? Hippocampus 11: 90-91.

Sandi C, Merino JJ, Cordero MI, Kruyt ND, Murphy KJ, Regan CM. 2003. Modulation of hippocampal NCAM polysialylation and spatial memory consolidation by fear conditioning. Biol Psychiatry 54: 599-607.

Savage LM, Chang Q, Gold PE. 2003. Diencephalic damage decreases hippocampal acetylcholine release during spontaneous alternation testing. Learn Mem 10: 242-246.

Schelling G. 2002. Effects of stress hormones on traumatic memory formation and the development of posttraumatic stress disorder in critically ill patients. Neurobiol Learn Mem 78: 596-609.

Schroeder JP, Packard MG. 2002. Post-training intrabasolateral amygdala scopolamine impairs foodand amphetamine-induced conditioned place preferences. Behav Neurosci 116: 922-927.

Schroeder JP, Packard MG. 2003. Systemic or intraamygdala injections of glucose facilitate memory consolidation for extinction of drug-induced conditioned reward. Eur J Neurosci 17: 1482-1488.

Shansis FM, Busnello JV, Quevedo J, Forster L, Young S, Izquierdo I, et al. 2000. Behavioural effects of acute tryptophan depletion in healthy male volunteers. J Psychopharmacol 14: 157-163. 
Schmitt U, Hiemke C. 2002. Tiagabine, a gammaamino-butyric transporter inhibitor impairs spatial learning of rats in the Morris water maze. Behav Brain Res 133: 391-394.

Selcher JC, Weeber EJ, Christian J, Nekrasova T, Landreth GE, Sweatt JD. 2003. A role for ERK MAP kinase in physiologic temporal integration in hippocampal area CA1. Learn Mem 10: 26-39.

Shinotoh H, Fukushi K, Nagtsuka S, Tanaka N, Aotsuka A, Ota T, et al. 2003. The amygdala and Alzheimer's disease: positron emission tomographic study of the cholinergic system. Ann NY Acad Sci 985: 411-419.

Sergeant N, Bombois S, Ghestem A, Drobecq H, Kostanjevecki V, Missiaen C, et al. 2003. Truncated beta-amyloid peptide species in preclinical Alzheimer's disease as new targets for the vaccination approach. J Neurochem 85: 15811591.

Southwick SM, Davis M, Horner B, Cahill L, Morgan CA $3^{\text {rd }}$, Gold PE, et al. 2002. Relationship of enhanced norepinephrine activity during memory consolidation to enhanced long-term memory in humans. Am J Psychiatry 159: 14201422.

Stephenson CM, Suckling J, Dirckx SG, Ooi C, McKenna PJ, Bisbrown-Chippendale $\mathrm{R}$, et al. 2003. GABAergic inhibitory mechanisms for repetition-adaptivity in large-scale brain systems. Neuroimage 19: 1578-1588.

Straube T, Frey JU. 2003. Involvement of betaadrenergic receptors in protein synthesisdependent long-term potentiation (LTP) in the dentate gyrus of freely moving rats: the critical role of LTP induction strength. Neuroscience 119: 473-479.

Summers MJ, Crowe SF, Ng KT. 2003. Memory retrieval in the day-old chick: a psychobiological approach. Neurosci Biobehav Rev 27: 219-231.

Sunram-Lea SI, Foster JK, Durlach P, Perez C. 2002. The effect of retrograde and anterograde glucose on memory performance in healthy young adults. Behav Brain Res 134: 505-516.

Szapiro G., Barros DM, Ardenghi P, Vianna MR, Choi $\mathrm{H}$, Silva $T$, et al. 2001. Facilitation and inhibition of retrieval in two aversive tasks in rats by intrahippocampal infusion of agonists of specific glutamate metabotropic receptor subtypes. Psychopharmacology 156: 397-401.

Szapiro G, Izquierdo LA, Alonso M, Barros DM,
Paratcha G, Ardenghi P, et al. 2000. Participation of hippocampal metabotropic glutamate receptors, protein kinase $\mathrm{A}$ and mitogen-activated protein kinases in memory retrieval. Neuroscience 99: 1-5.

Szapiro G, Vianna MR, McGaugh JL, Medina JH, Izquierdo I. 2003. The role of NMDA glutamate receptors, PKA, MAPK, and CAMKII in the hippocampus in extinction of conditioned fear. Hippocampus 13: 53-58.

Talley CP, Clayborn H, Jewel E, McCart R, Gold PE. 2002. Vagotomy attenuates effects of L-glucose but not D-glucose on spontaneous alternation performance. Physiol Behav 77: 243-249.

Taubenfeld SM, Milekic MH, Monti B, Alberini CM. 2001. The consolidation of new but not reactivated memory requires hippocampal C/EBP beta. Nat Neurosci 4: 813-818.

Taubenfeld SM, Wiig KA, Bear MF, Alberini CM. 1999. A molecular correlate of memory and amnesia in the hippocampus. Nat Neurosci 2: 309-310.

Taubenfeld SM, Wiig KA, Monti B, Dolan B, Pollonini G, Alberini CM. 2001. Fornix-dependent induction of hippocampal CCAAT enhancerbinding brotein [beta] and [delta] co-localizes with phosphoryçated cAMP response elementbinding protein and accompanies long-term memory consolidation. J Neurosci 21: 84-91.

Tronel S, Sara SJ. 2003. Blockade of NMDA receptors in prelimbic cortex induces an enduring amnesia for odor-reward associative learning. J Neurosci 2003. 23: 5472-5476.

Vallee M, Purdyu RH, Mayo W, Koob GF, LeMoal M. 2003. Neuroactive steroids: new biomarkers of cognitive aging. J Steroid Biochem Mol Biol 85: 329-335.

Vianna M.R., Alonso M., Viola H., Quevedo J., deParis F, Furman, M, ET AL. 2000. Role of hippocampal signaling pathways in long-term memory formation of a nonassociative learning task in the rat. Learn Mem 7: 333-340.

Vianna, MR, Cammarota M, Coitinho AS, Medina JH, Izquierdo I. 2003. Pharmacological findings on the molecular basis of memory extinction. Curr Neuropharmacol 1: 109-121.

Vianna MR, Coitinho A, Izquierdo I. 2004. Role of the hippocampus and amygdala in the extinction of fear-motivated learning. Curr Neurovasc Res 1: $55-60$.

Vianna MR, Igaz LM, Coitinho AS, Medina JH, 
Izquierdo I. 2003. Memory extinction requires gene expression in rat hippocampus. Neurobiol Learn Mem 79: 199-203.

Vianna MR, Izquierdo LA, Barros DM, Ardenghi PG, Pereira P, Rodrigues C, et al. 2000. Differential role of CAMP-dependent protein kinase in short-and long-term memory. Neurochem Res 25: 621-626.

Vianna MR, Szapiro G, McGaugh JL, Medina JH, Izquierdo, I. 2001. Retrieval of memory for fearmotivated training initiates extinction requiring protein synthesis in the rat hippocampus. Proc Natl Acad Sci USA 98: 12251-12254.

Viola $\mathrm{H}$, Furman M, Izquierdo LA, Alonso M, Barros DM, De Souza MM, et al. 2000. Phosphorylated cAMP response element-binding protein as a molecular marker of memory: Effect of novelty. $J$ Neurosci 20: RC112, 1-5.

Walker DL, Ressler KT, Lu KT, Davis M. 2002. Facilitation of conditioned fear extinction by systemic administration or intra-amygdala infusions of D-cycloserine as assessed with fear-potentiated startle in rats. J Neurosci 22: 2343-2351.

Walz R, Lenz G, Roesler R, Vianna MR, Martins V, Brentani RR, et al. 2000. Time-dependent enhancement of inhibitory avoidance retention and MAPK activation by post-training infusion of nerve growth factor into $\mathrm{CA} 1$ region of hippocampus of adult rats. Eur J Neurosci 12, 2185-2189.

Walz R, Roesler R, Quevedo J, Rockenbach IC, Amaral OB, Vianna MR, et al. 1999a. Dosedependent impairment of inhibitory avoidance retention in rats by imediate post-training infusion of a mitogen-activated protein kinase kinase inhibitor into cortical structures Behav Brain Res 105: 219-223.

Walz R, Roesler R, Barros DM, de Souza MM, Rodrigues C, Sant'Anna MK, et al. 1999b. Izquierdo I. Effects of post-training infusions of a mitogen-activated protein kinase kinase inhibitor into the hippocampus or entorhinal cortex on short- and long-term retention of inhibitory avoidance. Behav Pharmacol 10: 723-730.

Weeber EJ, Sweatt JD. 2002. Molecular neurobiology of human cognition. Neuron 33: 845-848.
Weeber EJ, Yiang YH, Elgersma Y, Varga AW, Carrasquillo Y, Brown SE, et al. 2003. Derangements of hippocampal calcium/calmodulindependent protein kinase II in a mouse model for Angelman mental retardation syndrome. J Neurosci 23: 2634-2644.

Weinberger NW. 2003. The nucleus basalis and memory codes: Auditory cortical plasticity and the induction of specific, associative behavioral memory. Neurobiol Learn Mem 80: 268-284.

Wetzel W, Ott T, Matthies H. 1976. Is actinomycin D suitable for the investigation of memory processes? Pharmacol Biochem Behav 1976. 4: 515-519.

Wilson RI, Nicoll RA. 2001. Endogenous cannabinoids mediate retrograde signaling at hippocampal synapses. Nature 41: 566-592.

Wilson RI, Nicoll RA. 2002. Endocannabinoid signaling in the brain. Science 296: 678-682.

Wilson MA, Tonegawa S. 1997. Synaptic plasticity, place cells and spatial memory: study with second generation knockouts. Trends Neurosci 20: 102106.

Xu AJ, Chen Z, Wanai K, Huang YW, Wei EQ. 2002. Effect of 3-1-(phenylmethyl)-4-piperidinyl]-1- (2,3, 4,5-tetrahydro-1H-1-benzazepin-8-yl)-1-propanone fumarate, a novel acethylcholinesterase inhibitor, on spatial cognitive impairment induced by chronic cerebral hypoperfusion in rats. Neurosci Lett 331: 33-36.

Xu X, Bazner J, Qi M, Johnson E, Freidhoff R. 2003. The role of telencephalic NMDA receptors in avoidance learning in goldfish (Carassius auratus). Behav Neurosci 117: 548-554.

Yang Y, Cao J, Xiong W, Zhang J, Zhou Q, Wei H, et al. 2003. Both stress experience and age determine the impairment or enhancement of stress on spatial memory retrieval. J Endocrinol 178: 45-54.

Zhen X, Du W, Romano AG, Friedman E, Harvey JA. 2001. The p38 mitogen-activated protein kinase is involved in associative learning in rabbits. J Neurosci 21: 5513-5519.

Zhu X, Sun Z, Lee HG, Siedlak SL, Perry G, Smith MA. 2003. Distribution, levels, and activation of MEK1 in Alzheimer's disease. J Neurochem 86: 136-142. 

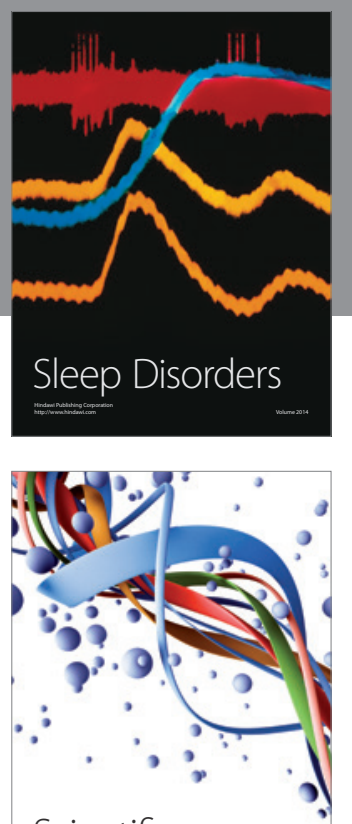

Scientifica
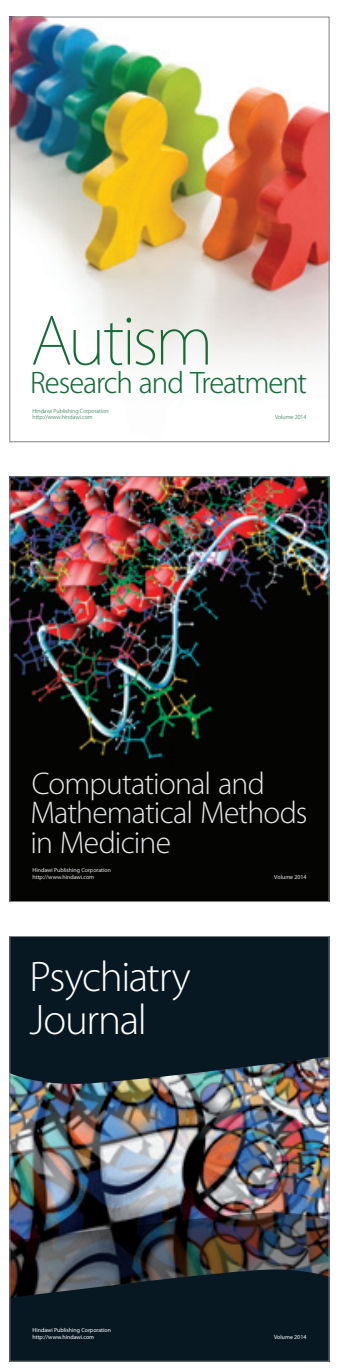
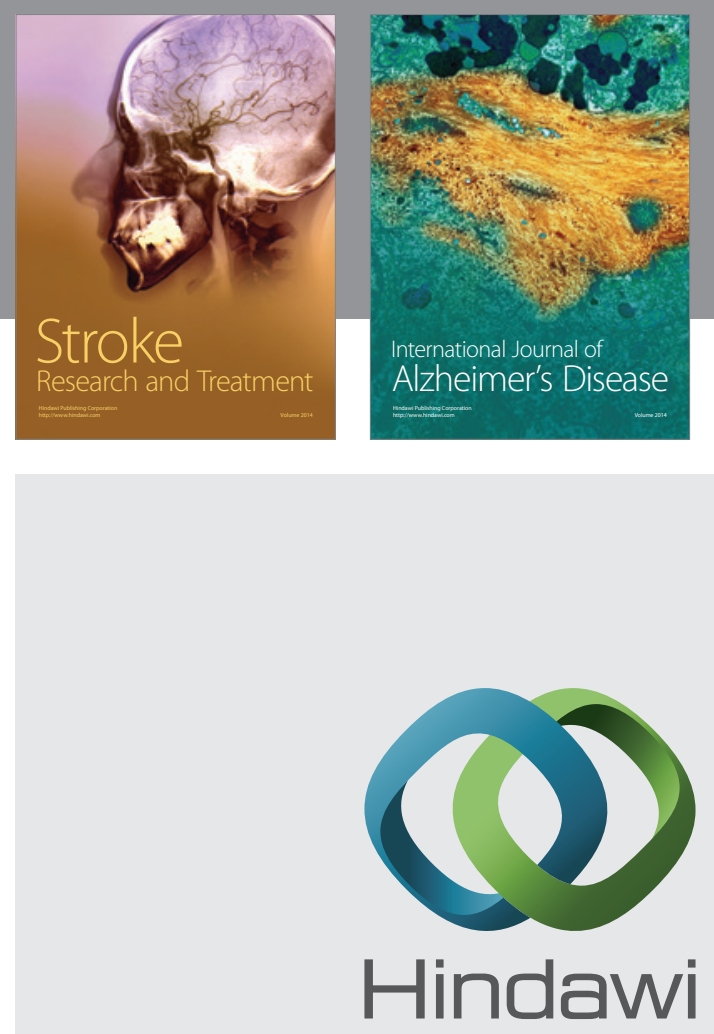

Submit your manuscripts at

http://www.hindawi.com
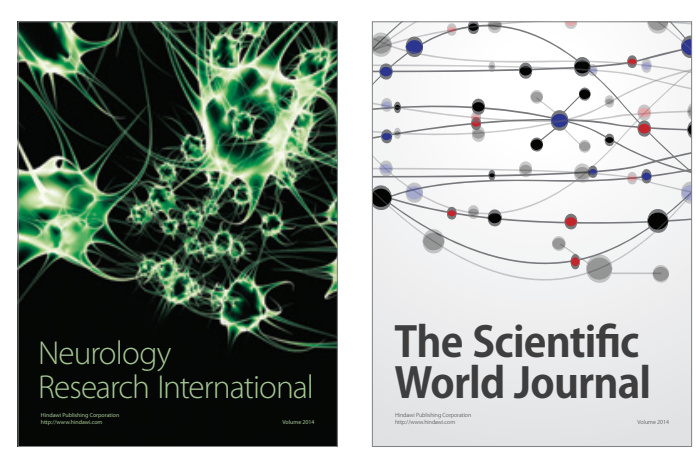

The Scientific World Journal

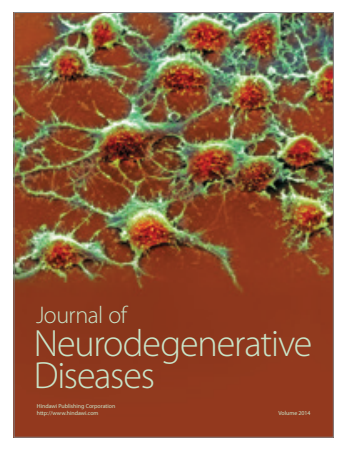

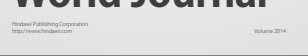

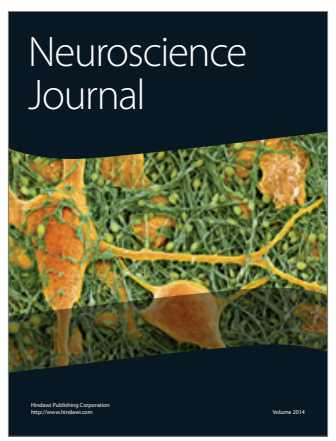

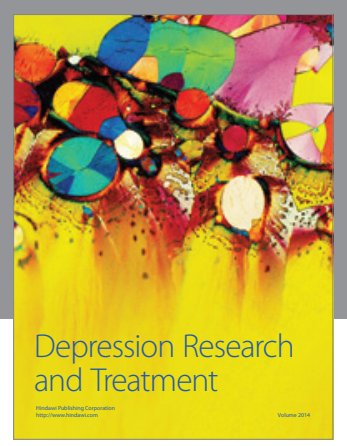
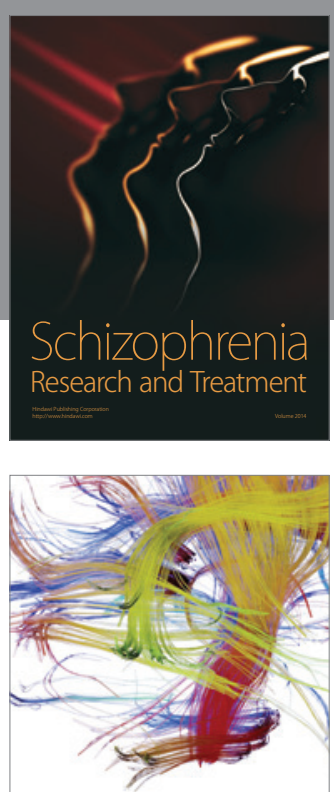

Brain Science

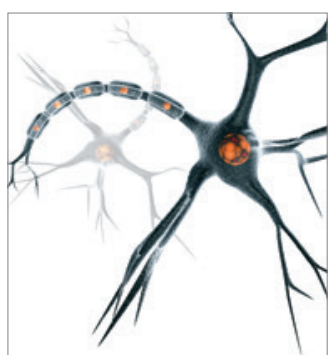

Neural Plasticity
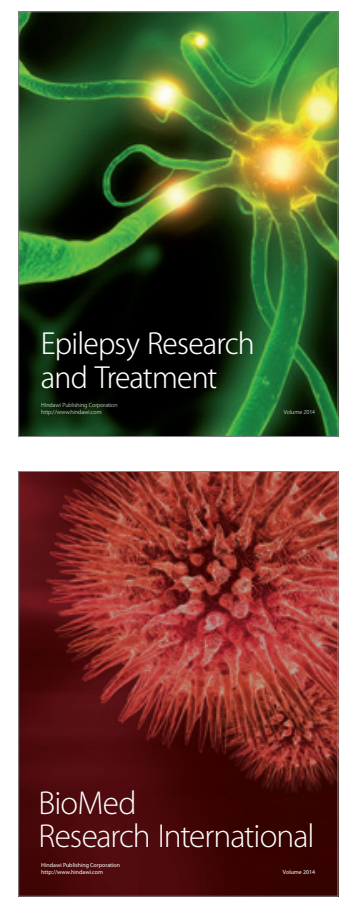

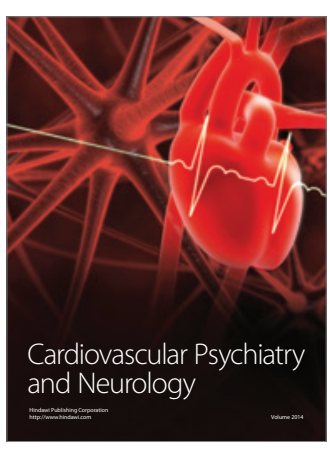

Parkinson's

Disease
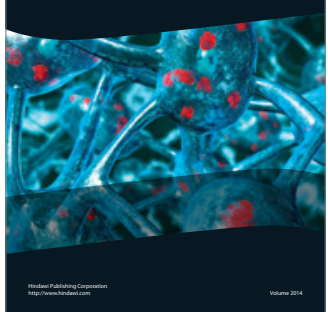